\title{
Aqueous two-phase system (ATPS): an overview and advances in its applications
}

\author{
Mujahid lqbal', Yanfei Tao ${ }^{1 *}$, Shuyu Xie” ${ }^{1}$, Yufei Zhu' ${ }^{1}$ Dongmei Chen ${ }^{1}$, Xu Wang ${ }^{1}$, Lingli Huang ${ }^{1}$, Dapeng Peng ${ }^{1}$, \\ Adeel Sattar ${ }^{1}$, Muhammad Abu Bakr Shabbir², Hafiz Iftikhar Hussain², Saeed Ahmed ${ }^{2}$ and Zonghui Yuan ${ }^{1,2^{*}}$
}

\begin{abstract}
Aqueous two-phase system (ATPS) is a liquid-liquid fractionation technique and has gained an interest because of great potential for the extraction, separation, purification and enrichment of proteins, membranes, viruses, enzymes, nucleic acids and other biomolecules both in industry and academia. Although, the partition behavior involved in the method is complex and difficult to predict. Current research shows that it has also been successfully used in the detection of veterinary drug residues in food, separation of precious metals, sewage treatment and a variety of other purposes. The ATPS is able to give high recovery yield and is easily to scale up. It is also very economic and environment friendly method. The aim of this review is to overview the basics of ATPS, optimization and its applications.
\end{abstract}

Keywords: Aqueous two-phase system (ATPS), Biomolecule separation, Solvent extraction, Veterinary drug residues

\section{History and background}

In 1896, Martinus Willem Beijerinck accidently found the ATPS while mixing an aqueous solution of starch and gelatin. However, its real application was discovered by Per-Åke Albertsson. Since then, the ATPS has been used for a range of purposes [1-3]. These systems can be formed by mixing a variety of components in water [4]. But two-polymer and polymer-salt (e.g., phosphate, sulfate or citrate) systems have grown rapidly and a lot of work has been put into studying this technique using these types of ATPSs [2]. This method has advantages over conventional extraction techniques like, environment-friendly, low cost, capable of continuous operation, ease of scaling-up and is efficient for many kinds of experiments specially for the concentration and purification of biomolecules $[1,2,4,5]$. The use of affinity ligands in ATPS can result in the higher recovery yields and higher purification folds of biological products as it is a primary stage recovery technique [6]. Affinity ligands can be covalently attached to polymer or polymer can also be modified with

\footnotetext{
*Correspondence: tyf@mail.hzau.edu.cn; yuan5802@mail.hzau.edu.cn ${ }^{1}$ National Reference Laboratory of Veterinary Drug Residues (HZAU)/MOA Key Laboratory of Food Safety Evaluation, Huazhong Agricultural University, Wuhan, Hubei 430070, China

Full list of author information is available at the end of the article
}

hydrophobic groups [5] Interested readers about aqueous two-phase affinity partitioning (ATPAP) are referred to an excellent review by Ruiz-Ruiz et al. [6].

Water as the main component of both phases in ATPS forms a gentle environment for biomolecules to separate and polymers stabilize their structure and biological activities [3, 4, 7-9] while other liquid-liquid extraction (LLE) methods could damage biological products because of the process conditions and organic solvents $[1,7]$. The purpose of this review article is to overview the technique extensively and its applications in detail.

\section{Types of aqueous two-phase system (ATPS)}

The most common biphasic systems are formed by two polymers (usually polyethylene glycol (PEG) and dextran) or a polymer and a salt (e.g., phosphate, sulfate or citrate). Other types include, ionic liquids and short-chain alcohols $[1,2,4,6,7,10,11]$. In addition to this, ionic and/or nonionic surfactants are used for the formation of micellar and reverse micellar ATPSs $[6,12,13]$. Polymer - polymer/salt systems have been studied for more than five decades. Polymer - polymer systems are preferably used for the separation, recovery and purification solutes sensitive to the ionic environment as these systems pose low ionic strength. While, high ionic strength is the only disadvantage of polymer - salts system [14]. Alcohol - salt ATPS are inexpensive as compared to polymers and copolymers. 
These systems are also characterized by low viscosity, easy constituent recovery, and reduced settling times, but a major drawback of using this type of ATPS is that many proteins are not compatible with alcoholrich phase $[15,16]$. The aqueous micellar two-phase system was first introduced by Bordier for the separation of integral membrane proteins [17]. These systems are also useful for ionic environment sensitive solutes as nonionic surfactants can be used for the formation of these systems. Mixed micellar systems are becoming popular for showing selectivity features [18]. Most recently, ionic liquids (ILs) based ATPSs are being developed [19]. Poly-phase systems (three or four polymer phases) also have been constructed for the separation of biomolecules [7]. One-polymer ATPSs have also been reported, which utilize only one polymer for the formation of ATPS in water [20]. PEGs of different molecular weights are widely used polymers in ATPS due to their low toxicity, low price and low volatile nature [21]. Table 1 shows different types of ATPS with representative examples.

\section{Two-phase formation, thermodynamics and partitioning}

Miscibility of solutions containing polymers is not a common phenomenon, this property of polymers results in the formation of two phases $[3,4,7]$. Similar incompatibility can be observed upon mixing a polymer and a high ionic strength salt. Polymer - polymer system forms large aggregates and because of steric exclusion, polymers start to separate between two different phases. In polymer salt ATPS, salt absorbs large amounts of water and a same exclusion phenomena can be observed [5, 22].

Phase separation in ATPS is affected by different factors like, concentration and molecular weight (MW) of polymer, concentration and composition of salt [21, 23]. The presence of salt also influences phase behavior which also bring changes according to the type and concentration. Although, the mechanism through which salt influence ATPS in poorly understood [1,7]. Generally, three forces: gravitational, flotation and frictional, act on a drop during phase separation and the balance between these forces determine its movement. The gravitational force depends on the density of drops while flotation and frictional forces depend on the flow properties of phases $[10,24]$. Surface properties of materials and components of ATPS determine the partitioning between two phases [7]. Poorly understood partition behavior is a major barrier in widely adaptation of ATPS on commercial levels for the purification of biomolecules [25].

Phase diagram (see Fig. 1) is like a fingerprint to a system under specific conditions (e.g., temperature and $\mathrm{pH}$ ) which is unique and shows the potential working area of ATPS. It provides a set of information like concentration of components for two phase formation and their concentration in the top and bottom phases $[4,26]$. The diagram (see Fig. 1) shows a binodal curve (TCB), which divides the region of component concentrations. This curve splits the concentrations which form two immiscible aqueous phases (above the binodal curve) from

Table 1 Types of ATPS with representative examples

\begin{tabular}{|c|c|c|c|c|}
\hline \multirow[t]{2}{*}{ Types of ATPS } & \multicolumn{3}{|l|}{ Representative examples } & \multirow[t]{2}{*}{ Reference } \\
\hline & Composition of ATPS & Product & Results & \\
\hline \multirow[t]{2}{*}{ Polymer - polymer } & PEG - dextran & Chitinase & $\begin{array}{l}\text { Successful partitioning of chitinase } \\
\text { towards bottom phase }\end{array}$ & [161] \\
\hline & PEG - dextran & $\begin{array}{l}\text { Nanospheres, nanowires and } \\
\text { DNA derivatized nanowires }\end{array}$ & $\begin{array}{l}\text { Successful In situ binding } \mathrm{Au} \\
\text { nanospheres with Au nanowires }\end{array}$ & [162] \\
\hline \multirow[t]{4}{*}{ Polymer - salt } & $\mathrm{PEG}-\mathrm{K}_{2} \mathrm{HPO}_{4}$ & B-phycoerythin & Recovery yield = $90 \%$ & [163] \\
\hline & & & Purification factor $=4$ & \\
\hline & PEG 4000 - sulfate $+8.8 \% \mathrm{NaCl}$ & a-Amylase & Purification $=53$ fold & [164] \\
\hline & & & Purity = $86 \%$ & \\
\hline \multirow[t]{2}{*}{ Alcohol - salt } & 2-propanol - $\mathrm{K}_{2} \mathrm{HPO}_{4}$ & Lipase & $\begin{array}{l}\text { Recovery yield = } 99 \% \text { Purification } \\
\text { factor }=13.5\end{array}$ & [165] \\
\hline & Ethanol $-\mathrm{K}_{2} \mathrm{HPO}_{4}$ & 2,3-butanediol & Recovery yield= >98 \% & [16] \\
\hline \multirow[t]{2}{*}{$\begin{array}{l}\text { Micellar/reverse } \\
\text { micellar ATPS }\end{array}$} & n-Decyl tetra (ethylene oxide) & Bacteriophages & $\begin{array}{l}\text { Bacteriophages partitioning } \\
\text { towards micelle poor phase }\end{array}$ & [12] \\
\hline & $\begin{array}{l}\text { Isooctane/ethylhexanol/methyltriocty| } \\
\text { ammoniumchloride }\end{array}$ & Plasmid DNA & $\begin{array}{l}\text { Successful purification of DNA } \\
\text { and RNA removal }\end{array}$ & [166] \\
\hline \multirow[t]{3}{*}{$\begin{array}{l}\text { lonic liquids (ILs) - } \\
\text { based ATPS }\end{array}$} & $\begin{array}{l}\text { 1-Butyl-3-methylimidazolium } \\
\text { chloride - salt }\end{array}$ & Codeine and papaverine & $\begin{array}{l}\text { Recovery yield }=>90 \% \text { (codeine), } \\
>99 \% \text { (papaverine) }\end{array}$ & [167] \\
\hline & Imidazolium - $\mathrm{K}_{2} \mathrm{HPO}_{4}$ & Curcuminoids & Extraction yield = $96 \%$ & [168] \\
\hline & & & Purity $=>51 \%$ & \\
\hline
\end{tabular}




\section{S 1}

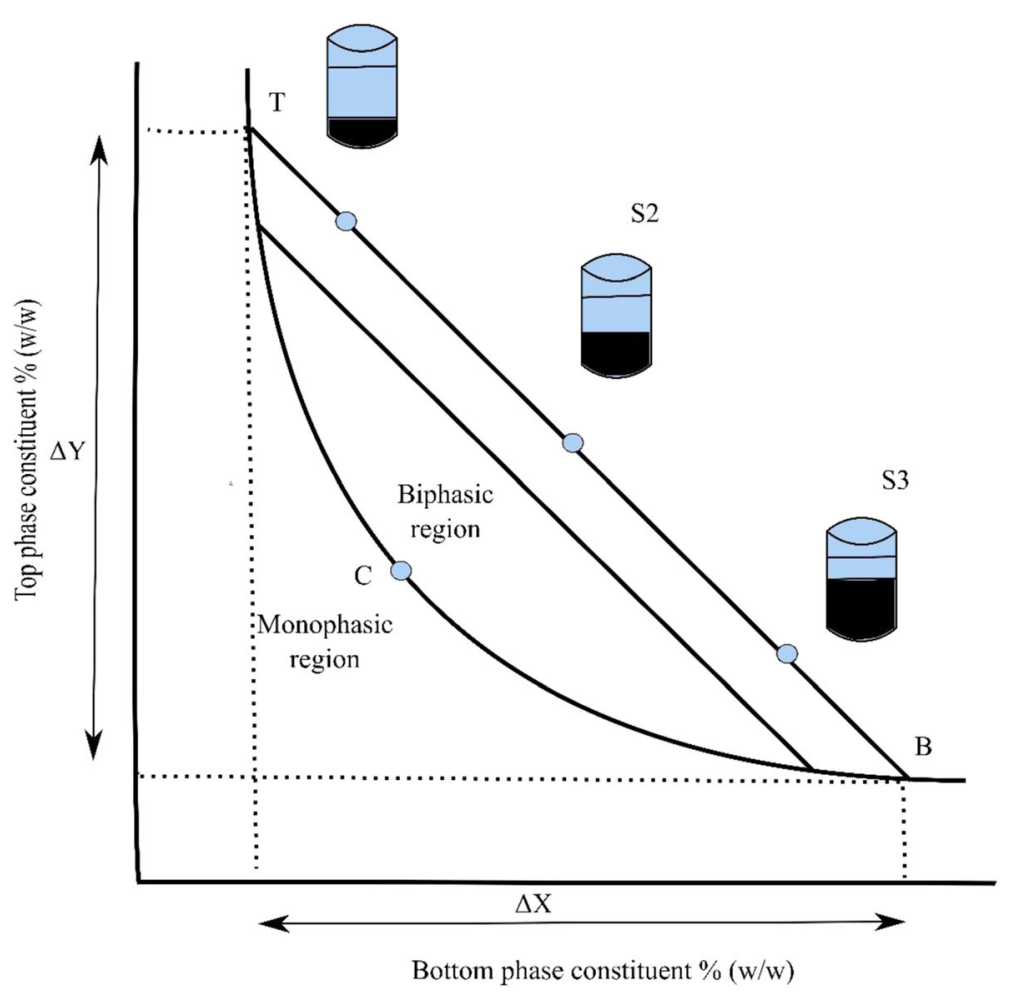

Fig. 1 Schematic representation of phase diagram. Concentrations above binodal curve (TCB) forms aqueous two-phase system

those that make one phase (below the binodal curve). The line (TB) in the diagram (see Fig. 1) is a tie line; it connects two nodes, which lie on the binodal curve. All the potential systems (e.g., S1, S2, S3) have same top phase and bottom phase equilibrium composition because of being on the same tie line. Point $\mathrm{C}$ on binodal is called as a critical point, just above this point the volume of both phases is theoretically equal. At point $C$ the value tie line length (TLL) is equal to zero. The tie line length and component concentration has same units. The tie line length can be estimated by using the weight ratio as shown in equation below;

$$
\frac{V_{t} \rho_{t}}{V_{b} \rho_{b}}=\frac{S B}{S T}
$$

Where $\mathrm{V}$ and $\rho$ stands for volume and density of top (t) and bottom (b) phases while SB and ST are segments lengths as shown in Fig. 1.

Or by the analysis of top and bottom phase, which is a more precise method;

$$
T L L=\sqrt{\Delta X^{2}+\Delta Y^{2}}
$$

The tie lines are commonly straight and the slope of tie line (STL) can be calculated with the help of equation 3 . This is also helpful in the construction of further tie lines.

$$
S T L=\frac{\Delta Y}{\Delta X}
$$

Binodal can be determined by three methods; turbidometric titration method, cloud point method and node determination method $[4,26]$. The researchers new to technique are referred to references $[3,4,8,27]$ for predetermined phase diagrams and methods for construction.

The equilibrium relationship between the top and the bottom phase of the ATPS determine the partition of biomolecules and the partition coefficient $(K)$ is defined as;

$$
K=\frac{\text { Conc }_{A T}}{\text { Conc }_{A B}}
$$

Where Conc. $A T$ is the concentration of component A in top phase and Conc. $A B$ is the concentration of $\mathrm{A}$ in the bottom phase at equilibrium [26]. So far, different models have been devised by the researchers to understand the partitioning in ATPS [25, 28-32]. There is no good comprehensive theory of liquid and liquid mixtures. In result, these models are based on the combination of different theories which makes a range of possible out-comes possible [33]. Albertsson's model has been used commonly to describe ATPSs. He suggested six different kinds of partitions, each having a different kind of driving force [34]. According to his model, 
partition behavior is determined by these factors, separately or collectively and the manipulation of some of these factors would dominate the overall behavior.

i. Electrochemical - where electrical potential drives the partition

ii. Hydrophobicity - where hydrophilic properties of molecules and phases determine the separation

iii. Bio-specific affinity - this kind of partition occurs when required molecules binds to a specific site on polymer

iv. Size - molecular size or surface area of molecules is dominating factor

v. Conformation dependent - where partition depends on the conformation of the molecule

The logarithmic form of the factors of partition coefficient can be expressed in equation (5).

$$
\begin{aligned}
\ln K= & \ln K^{o}+\ln K_{\text {elec }}+\ln K_{\text {hfob }} \\
& +\ln K_{\text {affinity }}+\ln K_{\text {size }}+\ln K_{\text {conf }}
\end{aligned}
$$

Where elec stands for electrochemical, hfob, affinity, size and conf denote as hydrophobic partitioning, affinity partitioning and conformation while $K^{o}$ include all other factors (e.g., environmental factors) [1, 3-5, 34]. Different theoretical and experimental models have been published by researchers. As, Andrews and Asenjo consider hydrophobicity as the main ruling factor of partition in polymer - polymer and polymer - salt ATPSs for protein $[5,35,36]$.

\section{Factors influencing partitioning in ATPS}

Since the partitioning mechanism in ATPS is still unknown. Most of the ATPSs are optimized according to the physicochemical properties of solutes of biomolecule. Different review articles $[1,5]$ and books $[3,27,37-39]$ discuss these factors in detail. Main factors influencing partition behavior in ATPS are:

\section{Molecular weight (MW) and concentration of polymer}

As most of the ATPSs are composed of polymer - polymer/salt. MW of polymers greatly influence the partition. Generally,

- $\uparrow \mathrm{MW}$ of polymer $\rightarrow \downarrow$ concentration of polymer required for phase formation

- $\uparrow$ Differences between the MW of polymers $\rightarrow \uparrow$ asymmetrical curve of the phase diagram

- $\uparrow \mathrm{MW}$ of PEG $\rightarrow \downarrow$ value of $K$

In a polymer - salt system, partition towards polymerrich phase decreases upon increasing the concentration of polymer while in a polymer - polymer system partition decreases towards phase having high MW polymer. The main reason behind this phenomenon is the increase in the steric exclusion of biomolecule from that phase or because of changes in the hydrophobicity of phases $[1,5,27]$ As increase in the MW of polymer increases hydrophobicity by reducing the hydrophilic groups/hydrophobic area [5].

\section{Hydrophobicity}

Hydrophobicity play an important role in the partitioning of protein. Two main effects: phase hydrophobicity effect and salting out effect, are involved in hydrophobic interactions [5, 40, 41]. In polymer - salt systems, hydrophobicity may be manipulated by varying TLL, MW of polymer and by adding a salt (e.g., $\mathrm{NaCl}$ ). The low $\mathrm{NaCl}$ concentrations $(<1 \mathrm{M})$ do not affect ATPS however, high salt concentrations $(>1 \mathrm{M})$ changes the phase diagram [35]. The addition of salt in ATPSs has a significant effect on the partition coefficient [42]. These salts contain ions of different hydrophobicities and the hydrophobic ions force the partitioning of counter ions to phase with higher hydrophobicity and vice versa. The salting-out effect moves the biomolecule from salt-rich phase to polymer-rich phase [26].

\section{$p H$}

The $\mathrm{pH}$ of ATPS may alter the charge and surface properties of solute which affects the partitioning of biomolecule. The net charge of the protein turns negative in case of higher $\mathrm{pH}$ than the isoelectric point (pI) and positive if lesser than $\mathrm{pI}$. If the $\mathrm{pH}$ is equal to $\mathrm{pI}$, net charge will be zero [26]. It has been reported that the partitioning of negatively charged biomolecule in a higher $\mathrm{pH}$ system increases the partition coefficient and target biomolecule prefers top phase. Higher $\mathrm{pH}$ values than $\mathrm{pI}$ of protein induce an affinity towards PEG-rich phase because of the positive dipole moment $[40,43]$.

\section{Temperature}

Temperature greatly affects the composition of two phases in an ATPS, hence, the phase diagram. The changes in temperature also affect partition through viscosity and density. Therefore, it is always recommended by the researchers to have a strict control of temperatures in ATPS related experiments. In general, phase separation is obtained at lower temperature in a polymer - polymer ATPS with lower concentrations of polymer, however, an opposite effect is seen in polymer - salt system [27].

Partitioning behavior of biomolecule and phase separation rate is also influenced by the physico-chemical properties (i.e., density, viscosity and interfacial tension) of ATPS. Measurement of such properties have been explained by Albertsson [3], Zaslavsky [37] and Hatti-Kaul [4]. 


\section{Optimization of aqueous two-phase system}

Since the partitioning behavior of biomolecules in ATPS is complex, many laborious trials have to be performed for the optimization of these systems. This optimization leads to an increased overall-cost [44]. One conventional way to optimize ATPS is a one-factor/variable-at-a-time (OFAT) in which specific factors are identified to study, but the major disadvantage of OFAT approach is not considering the interaction between the factors as the name indicate, one factor is studied at a time while keeping all factors constant. This usually results in the poor and false optimal conditions [26, 44, 45]. Nowadays, a multivariate statistical technique is used for the optimization of ATPS called "Design of Experiments (DoE)". DoE consists of few experiments at a specific factor level combination [26, 44]. The general steps in a DoE are:

\section{Screening of variables}

First step in a DoE process is the screening of significant factors $(k)$, which demands further investigation because of their great influences on the out responses [26, 45, 46]. This is usually done by full factorial design (FFD) and fractional factorial design (fFD). In these designs all factors $(k)$ are assigned two levels, high (+) and low (-). In FFD, experiments are carried out at different combinations of the factors with a total number of $2^{k}$. For instance, the number of factor is 2 (e.g., A and B). Then the possible number of experiments to be conducted is $2^{2}=4$ resulting in the combinations of $(-,-),(+,-),(-,+)$ and $(+,+)$. No doubt, this factorial design gives high accuracy results along with the possible interaction between the factors, but the number of experiments will be more in case of more factors (e.g., $2^{5}$ ) [26, 44-46]. To control this drastic increase in the number of experiments to one-half, one-quarter or a higher fraction of full fraction, fFD is used, which is denoted as $2^{k-1}, 2^{k-2}$ and $2^{k-4}$. Another method used for the screening is Plackett-Burman design (PBD), a linear screening approach, used when only main influences are of interest $[26,44]$. This could be represented in the form of the equation as follows

$$
y=\beta_{0}+\sum_{i=1}^{k} \beta_{i} X_{i}+\varepsilon
$$

(Here, $y=$ predicted response variable, $\beta_{0}$ and $\beta_{i}=$ coefficient of regression, $\mathrm{X}_{\mathrm{i}}=$ experiment factor and $\varepsilon=$ random error).

Finally, in all three screening designs (FFD, fFD and PBD) the magnitude of the significant factors is analyzed by using analysis of variance (ANOVA) [26, 44, 47].

\section{Initial optimization}

After the screening of factors/variables, the next step is to confirm the optimum level of these factors. As it is important to check that the factors are near to the optimal experimental region. This is done by an analysis of the model curvature after adding few center points experiments to screening model. Upon significant difference between these center point experiments and average out-put responses a model curvature occurs. This means the responses are situated in the optimal region and can be optimized in the next step which is not possible in case of no significant difference [26, 44, 45]. If no curvature exists, steepest ascent and steepest descent experiments are performed to increase or decrease the out-put responses to reach the proximity of optimal region $[26,44,48]$. Steepest ascent/descent experiments are useful in the determination of experimental direction. These experiments are initially performed at the center point of the significant factors and each factor level is increased or decreased in accordance with the magnitude of main effects. [26, 44]. In addition to this, these experiments have to be performed until no more increase in the out responses is observed, thus the general vicinity of the optimal experimental region can be drawn from the maximum response point of these experiments. Finally, these points can be taken as center points for final optimization [26, 44].

\section{Final optimization}

Response surface methodology (RSM) is used for the final optimization of significant factors. Box and Wilson first reported this optimization approach [49]. This methodology is useful in the determination of optimal operating conditions and significant independent factors or their interactions with dependent output responses in the multivariate complex system (e.g., ATPS) [44, 50]. RSM is helpful in the prediction of responses by investigating an optimal experimental region and collecting experimental data which fits quadratic equation/second-order polynomial model [26, 44]. In this context, regression analysis is performed to select the best data representing equation and then output responses are analyzed by surface or contour plots [51]. Central composite design (CCD) and Box-Behken design (BBD) are two different multilevel designs of RSM but the CCD is most commonly used because of rotatability and uniform precision $[45,51]$. CCD is also an extensively used model for the optimization of ATPS (PEG - Salt) [44, 51]. However, according to Raja et al., BBD has advantages over CCD, like, less number of experiments are done in $\mathrm{BBD}$ as compared to $\mathrm{CCD}$ and there are 3 factor levels in BBD while 5 in CCD [26]. Finally, the experimental data of these methods are used for fitting a full quadratic model and analyzed by regression analysis $[26,44]$. 


\section{Analysis of model}

After the optimization of significant factors in the previous step the quadratic equation obtained has to be solved analytically to determine the optimum values. Statistical software, for example Minitab $^{\circ}$, Design-Expert ${ }^{\circ}$ and Matlab $^{\circ}$, which are being used in many fields for different applications [52-56], can also be used for this purpose. This analysis provides the optimum level of significant factors which maximize the response of model $[26,44,45]$.

\section{Validation of model}

In the final step of DoE experiments are performed using predicted values. Results are compared with those predicted values. If there is a small difference between predicted response and actual response, then the validation of the model is confirmed [26, 44, 46, 50,57].

\section{Applications of aqueous two-phase system (ATPS) Proteins}

Downstream processing is a very important step in the purification and separation of biomolecules in terms of cost. Specially, protein processing requires many steps for the purification because of complex starting material $[1,58]$. Therefore, the demand for a high yielding and economical method for purification is increasing by the time. Chromatography of protein is not a suitable method to apply on a large scale due to batch processing and large pressure drops. Aqueous systems composed of organic solvents are not considered suitable for the purification of proteins because of their low solubility in these systems $[5,59]$. To overcome such limitations, research is being focused on ATPS [58]. That's why, the protein recovery from crude feedstocks at large-scale has been done by ATPS and this application of ATPS has attracted the most interest [7]. Protein partitioning in both phases mainly depends on the components of ATPS and their surface properties [5]. Mostly, protein will accumulate in top, hydrophobic and less polar phase, usually PEG. Proteins can be separated from one to another by changing MW of polymer, ion type or ionic strength in salt phase with the help of an additional salt $(\mathrm{NaCl})$. These changes will affect the partition coefficient of protein partitioning.

Thaumatin is a low-calorie protein sweetener. In 1990, Cascone et al., studied the partition behavior of thaumatin from disrupted cells of $E$. coli in PEG - dextran and PEG - salt (phosphate) ATPSs. They investigated the effects of changes in phase forming components on partition coefficient $K$ and observed that, MW of PEG, pH and the concentration of additional salt $(\mathrm{NaCl})$ can alter $K$. While found no effect of protein concentration up to $40 \mathrm{gL}^{-1}$. Analysis of protein was done by reverse-phase high performance liquid chromatography (HPLC). Purification conditions resulted in a 90-95\% recovery yield and 20fold purification in a single step [60].

In order to find the partitioning behavior of biomolecule for the industrial scale-up ATPS, Diamond and Hsu published a generalized expression of protein partitioning in PEG - dextran ATPS by utilizing the modified version of Flory-Huggins theory. According to the expression, natural $\log$ of protein coefficient relates to the concentration difference of polymer between the two phases. The parameters of the relation were protein-water, proteinpolymer and polymer-water interaction, function of protein and MW of phase forming polymer and the difference of electrostatic charge between phases. They also verified the relationship by observing the partition behavior of 17 different MW proteins [61]. In 1996, Hachem et al., concluded hydrophobicity as a dominant factor of partitioning pattern of proteins in ATPS, especially in polymer - salt (PEG - $\left.\mathrm{PO}_{4}\right)$ systems. They also observed that MW of proteins does not contribute in the partitioning, which confirms that attractive interactions (hydrophobic) between the polymer and proteins are responsible for protein partitioning [36]. Franco et al., established a method to study the effect of protein surface hydrophobicity on partitioning in ATPS. The experiments were conducted on two different series of hydrophobically modified proteins. They noticed the increase in the valve of $R$ (separation power) upon the addition of $\mathrm{NaCl}$ in PEG - phosphate, which shows an important effect on system resolution for protein surface hydrophobicity. Protein surface hydrophobicity was twice as high when compared with the ATPS without $\mathrm{NaCl}$. The same increase in the value of $R$ was observed by Hachem and co-workers. Andrews and Asenjo, both were the part of these teams they strongly believe in the hydrophobicity as a single property on partitioning [35, 62]. Controlling partition of proteins by manipulating the temperature is a universally applicable method irrespective of the nature of the phases. Belval et al., discussed same phenomena in 1998, when they partitioned proteins in PEG - potassium phosphate system [63]. Liu and co-workers, utilized a nonionic surfactant $n$-decyl tetra (ethylene oxide), $\mathrm{C}_{10} \mathrm{E}_{4}$, for the purification and concentration of proteins and viruses. This nonionic surfactant separates into two coexisting micellar phases in the water by an increase in the temperature. In their opinion, high water content in both phases and nondenaturing property of nonionic surfactant make this system potentially useful for purification and concentration of proteins and other biomolecules even at industrial scale [12]. Dodecyltriethylammonium bromide and sodium dodecylsulfate surfactants were used by Xiao et al., in 2000 for protein partitioning. They observed the concentration of negative charged BSA in surfactant-rich and positive charged lysozyme 
in surfactant-depleted phase in a cationic system while in anionic system opposite pattern of partitioning was observed [13]. Kresheck and Wang developed a new micellar ATPS for the separation of six typical globular proteins using $n$-dodecyldimethyohosphine oxide (APO12) and studied the effect of several factors [64]. Most of the previous studies explain partitioning on a molecular level or on basic thermodynamic theory, but, the kinetics of the separation process was ignored until Merchuk et al., reported their studies. They discussed the phase inversion in ATPS for protein separation which is very important for finding an optimal design in simulation schemes [65]. Fan and Glatz showed the charged protein (T4 lysozymes) partitioning in two polymer ATPS with salt effects as examination of charge effects is incomplete without considering the effect of salts [37]. They observed that increase in the concentration of salt shifts relatively more protein from the bottom to top phase and change in concentration of salt also influence electrostatic and non-electrostatic interactions [66].

"Smart polymers" are used for making one polymer ATPS instead of conventional two polymers or polymer/ salt ATPS. Johansson et al., also used similar system for protein (lysozyme, bovine serum albumin and apolipoprotein A-1) purification. They used a linear random copolymer composed of ethylene oxide and propylene oxide (EOPO), hydrophobically modified at both ends with myristyl groups, (HM-EOPO). An ATPS composed of HM-EOPO forms a top phase of almost $100 \%$ water and a bottom phase containing 5-9 \% polymer. Their results showed the novelty of the system as it uses one polymer which can also be recovered and operated at moderate salt concentrations and temperature [20]. Alves and co-workers analyzed the partitioning of proteins from cheese whey, porcine insulin and bovine serum albumin (BSA). Results showed that $\alpha$-lactalbumin $(\alpha-\mathrm{La})$ concentrate in PEG-rich phase and $\beta$-lactoglobulin $(\beta$-Lg) in saline phase in a system composed of $14 \%$ PEG1500 $18 \%$ potassium phosphate. While in PEG1400 - maltodextrin $4000(\mathrm{MD})$ system, $\beta$-Lg and BSA concentrate in MD rich-phase and porcine insulin showed affinity for PEG-rich phase [67]. Aqueous two-phase extraction (ATPE) has been used for the purification of proteins from different sources. Transgenic crops are utilized as expression hosts [68] and tobacco as a host produce recombinant protein, but the handling of its large biomass is a challenge. In order to develop a cost effective method to deal with huge biomass, Balasubramaniam et al., studied the purification of such proteins by ATPE with egg white lysozyme as a model protein. Their results declared ATPE a suitable method for partial purification of protein from tobacco [69]. Corn has also been used as an expression host for recombinant proteins. Gu and Glatz used ATPS for the extraction of recombinant protein from corn endosperm and germ [68]. Ferreira and co-workers showed the optimization of protein partitioning from Zea mays in PEG6000 - $\mathrm{CaCl}_{2}$ with the help of RSM. Results showed no influence of $\mathrm{pH}$ on phase diagrams and tie line length. RSM analysis showed, high $\mathrm{pH}$ and larger tie line length as favorable conditions for the recovery of proteins. The method was validated as the achieved partition coefficient (4.2) was in the range of theoretical partition coefficient (4.1-4.3). This process was also promising for continuous ATPSP due to the proteins ( $\alpha$ and $\beta$-amylases) stability [70].

Protein extraction from urine can be useful for the diagnosis of several diseases (e.g., diabetes mellitus) and also in assessing the effectiveness of therapies. A healthy individual excretes less than $150 \mathrm{mg}$ of protein in urine per day, but this may exceed to a few grams per day in renal diseases [71, 72]. In 2007, Wang et al., for the first time reported the extraction of protein from human urine with the help of IL-ATPS. They used an ATPS containing 1-butyl-3-methylimidazolium chloride $(\mathrm{BmimCl})$ and $\mathrm{K}_{2} \mathrm{HPO}_{4}$. Protein was extracted into the BmimCl-rich top phase while contaminants were separated in $\mathrm{K}_{2} \mathrm{HPO}_{4}$ bottom phase [72]. Pei and co-workers also formed an IL (imidazolium) based ATPS to extract bovine serum albumin, cytochrome c, trypsin and $\gamma$-globulins. They observed the influence of various factors on the extraction efficiency and found that increasing temperatures and alkyl chain length IL increase the extraction. However, increase in $\mathrm{pH}$ slightly changes the extraction of cytochrome c. The system was found to be useful as the conformation of proteins was not affected because of the quick phase separation, lower viscosity and little emulsion formation. Thermodynamics studies showed hydrophobicity as the main driving force. Results depicted that $75-100 \%$ extraction of proteins in IL-rich phase could be achieved in this system [73]. In 2008, Saravanan et al., observed the partitioning behavior of two model proteins (ovalbumin and myoglobin) in a two polymer (PEG - poly acrylic acid, PAA) ATPS and studied the influence of different factors. PEG4000 was found to be allowing better partitioning and the overall system was found to be suitable for low MW proteins. Moreover, $1 \mathrm{M} \mathrm{NaCl}, 20{ }^{\circ} \mathrm{C}$ and a $\mathrm{pH}$ of 8.0 indicated better partitioning. The maximum yield of ovalbumin and myoglobin were $87.4 \%$ and $95.2 \%$ respectively. Overall the system was potential for the extraction of soluble proteins [74].

Several research articles regarding ATPS for protein partitioning have been published. Fisher et al., reported nanoparticle mediated protein separation in micellar systems with high recovery yields $[75,76]$. IL-based ATPSs are being used in current scenario [77]. However, most recently, Li et al., showed the extraction of protein using deep eutectic solvent (DES) - ATPS. They selected Betaine-urea for extraction and studied the influence of 
$\mathrm{pH}$, temperature, salt concentration, separation time, amount of protein and the mass of DES. More importantly, the conformation of protein was not changed and the extraction efficiency was $99.82 \%$. All the results suggested betaine-based DES - ATPS a potential new system for protein separation [78].

\section{Enzymes}

Conventional liquid-liquid extraction techniques are generally not applicable for the purification of enzymes due to the irreversible loss of enzymatic activity [27]. Other constraints of these traditional purification techniques are laborious procedures and low yields $[79,80]$. Ultrafiltration and hydrophobic interaction chromatography are also multi-step, costly and low-yielding purification techniques. Affinity and ion exchange chromatography are the two most frequently used chromatography techniques for the purification of recombinant enzymes. But a sample pretreatment step is required to facilitate the capture of the target protein. Ion exchange chromatography requires a desalting step while using LB media, which is the commonly used media and contain salt and yeast extract. Metal affinity chromatography is also impossible as yeast extract is known to contain cysteine rich protein [81]. Thus, ATPS was developed to overcome such limitations $[82,83]$. It is also capable of combining different downstream processes into a single step [83, 84].

Microbial lipases are ubiquitous enzymes that are considered to be very important biocatalysts because of their substrate specifities and diversified properties [80, 85]. These enzymes are essential for a number of biotechnological applications. However, crude lipases contain isoforms and lipolytic proteins which results in the form of less biocatalytic reactions [80]. Ramakrishnan et al., studied typical polymer - salt (PEG - phosphate) ATPS for the extraction of an intracellular lipase from a lactic acid bacterium, Enterococcus faecium. In a PEG8000 $\mathrm{NaH}_{2} \mathrm{PO}_{4}$ system result showed the partition towards sodium dihydrogen phosphate-rich bottom phase. After ultrafiltration, activity recovery was $5.99 \%$ and purification factor of $82.09 \%$ was achieved. In addition to this enzyme characterization study revealed that this enzyme was of alkaline nature and the MW of purified lipase was $19.2 \mathrm{kDa}[80]$.

Laccases are another group of enzymes, which are found in plants, insects, bacteria and fungi. Fungal laccases have been purified and characterized extensively. They are successfully being used for pharmaceutical products (e.g., antibiotics, anticancer drugs, anesthetics and sedatives). Recently, in 2016, Rajagopalu et al., purified laccase from Hericium erinaceusi using PEG8000 - potassium phosphate ATPS and achieved a recovery $99 \%$ [83].

Xylanases enzymes have been used in various applications, one of the major use is in the pulp and paper production as it can degrade the backbone of hemicellulose xylan [81, 86]. In 2016, Rahimpour et al., studied the two-stage purification of xyalanase using a $6 \%$ PEG 6000-20 \% phosphate system at first stage. Results showed about $78 \%$ of recovery after final separation and a purification factors of 6.7 [81]. Packed columns are being used for enzyme purification because they require small space and are more efficient because of reduced axial mixing. A recovery of $94 \%$ of xylanase was achieved by Igarashi et al., by PEG 4000 - dipotassium phosphate ATPS [87]. Elastase extraction from Bacillus sp. EL31410 was done by $\mathrm{Xu}$ and co-workers using an optimized ATPS of $23.1 \%$ PEG2000 - $11.7 \% \mathrm{KH}_{2} \mathrm{PO}_{4} /$ $\mathrm{K}_{2} \mathrm{HPO}_{4}$ with a predicted recovery of $89.5 \%$ [57].

\section{Monoclonal Antibodies (mAbs)}

Antibody based therapies have played a key role in the treatment of infectious diseases, autoimmune disorders and cancers. Several antibodies have been approved by the US Food and Drug Administration (FDA) [47, 88]. This biopharmaceutical market has been steadily increasing since the day, FDA approved the first $\mathrm{mAb}$ (Orthoclone OKT3) and the global market has been projected to reach US $\$ 497.9$ billion by the end of this decade [89]. Thus, these therapeutic agents have become very important and the demand of cost-effective, scalable and effective antibodies is increasing day by day. Improvements have been made in the upstream and downstream productivity as larger doses of mAbs achieve the required efficacy as compared to other therapeutic bioproducts, such as vaccines, hormones and growth factors [90]. These purification improvements are also necessary to meet the purity standards of therapeutic molecules [88]. ATPS has proved to be a practical tool for the purification of mixture of biomolecules [47, 91]. Although, ATPE in the downstream processing of antibodies has been confined to the research studies only [90].

For first time, ATPS was used by Sulk et al., with thiophilic absorption chromatography for the isolation of IgG1 mAbs against horseradish peroxidase from hybridoma cell culture supernatant and recovery was $91 \%$ after ATPE. The overall recovery was $71 \%$ with a purification factor of 6.2 [92]. In 2007, Rosa et al., described the partitioning of immunoglobulins in two types (polymer-polymer and polymer - salt) of ATPS. Pure IgG was first extracted into a PEG-rich phase and then phosphate-rich phase. The purification factor was 2.7 and 5.9 respectively. They showed the purification of human IgG from an artificial mixture of proteins containing human serum albumin and myoglobin using PEG 3350 - phosphate with $100 \%$ recovery and a purity of $99 \%$ [88]. In another research work by the same authors, they reported the recovery of human IgG from Chinese hamster ovary $(\mathrm{CHO})$ and hybridoma cell 
culture supernatant using PEG 6000 - phosphate [93]. An 88 and $90 \%$ recovery yield in polymer rich phase were obtained, respectively. In 2009, Rosa et al. described that multistage equilibrium ATPE has advantages over single-stage experiment regarding recovery yield and purity. As $89 \%$ of IgG was recovered in PEG-rich phase with $75 \%$ of purity while in single-stage experiment $61 \%$ recovery yield and $55 \%$ protein purity were achieved. All factors (phase forming components, $\mathrm{NaCl}$ concentration, $\mathrm{pH}$ and volume ratio) were kept constant [90]. High concentrations of $\mathrm{NaCl}$ were found necessary for high recovery yields, but this may be a limitation during the scale-up. As, high concentration of $\mathrm{NaCl}$ is capable of damaging the equipment because of corrosive properties. The same year, Rosa and co-workers published another study of the downstream processing of antibodies using ATPS composed of PEG3350, dextran and triethylene glycol diglutaric acid (TEG-COOH). Single-stage and multistage strategies were evaluated and compared. In the single stage extraction system, they investigated the effect of $\mathrm{pH}$, TEG-COOH concentration and volume ratio on the partitioning of antibodies in $\mathrm{CHO}$ supernatant and showed that high TEG-COOH concentrations and lower $\mathrm{pH}$ is suitable for the selective extraction of IgG in PEG-rich phase. Most productive conditions of single-stage extraction were $1.3 \%(\mathrm{w} / \mathrm{w})$ TEG-COOH and a volume ratio of 2.2 which resulted in $96 \%$ recovery $87 \%$ protein purity and a total purity of $43 \%$. The final IgG concentration was $0.21 \mathrm{mg} / \mathrm{ml}$ [94]. In order to increase both recovery yield and purity simultaneously, an affinity-enhanced multistage was simulated in which IgG was purified in a PEGrich phase. This stage showed a final concentration of $1.04 \mathrm{mg} / \mathrm{ml}$ with a protein purity of $93 \%$. PEG/dextran ATPS was containing $1.3 \%(w / w)$ TEG-COOH [94].

Upstream technology for the production of IgG has been considerably improved to gain higher titers and to keep this increasing, it is essential to solve the downstream processing that has been proving to be a bottleneck previously $[93,95,96]$. In this regard, Azevedo et al. studied the incorporation of ATPS, hydrophobic interaction chromatography (HIC) and size-exclusion chromatography (SEC) for the purification of IgG from a $\mathrm{CHO}$ cell supernatant. ATPS was composed of $10 \%$ (w/ w) PEG 3350 and $12 \%(w / w)$ citrate, which allowed the concentration of IgG in citrate-rich phase with $97 \%$ yield and $72 \%$ protein purity and $41 \%$ HPLC purity. This phase was then purified on phenyl-Sepharose HIC column using a citrate mobile phase. It resulted in the $86 \%$ HPLC purity and $91 \%$ protein purity. On third the step, SEC was allowed to final polishing. IgG aggregates were removed by injecting HIC-eluted fractions in a Superose 6 size-exclusion column. Finally, a $100 \%$ pure IgG was obtained with $90 \%$ yield [95].
Downstream processing can cost up to $80 \%$ of the overall production cost [94] and phase separation by gravity in the downstream process is time consuming, which ultimately lead to an escalating production costs [6, 87, 97, 98]. To overcome this limitation column extractor are used which do not require centrifugation for phase separation. Rosa et al. evaluated the performance of a packed differential contractor with ATPE of IgG from a $\mathrm{CHO}$ cell supernatant. They selected PEG-rich phase as the disperse phase and the stainless steel as column packing bed after preliminary studies. The hydrodynamics of the stainless steel was also studied and the data were successfully adjusted to the Pratt-Thornton, Richard-Zaki and Mísek equations. The results showed the recovery yield of $85 \%$ of IgG and $84 \%$ protein purity [97]. In 2012, Silva et al. designed an ATPS in microfluidic device for the extraction of mAbs as, microscale process techniques are cost effective. They tagged IgG with fluorescein isothiocyanate (FITC) in an ATPS, composed of PEG/phosphate with $\mathrm{NaCl}$. Fluorescence microscopy was used for the measurement of the phenomena of diffusion and partition of IgG from salt-rich phase to PEG-rich phase. These microscale results were found in accordance with macroscale results upon comparison except the reduction in the operation time [98].

A typical approach in the downstream processing of the mAbs includes concentration, selective purification and virus elimination. Selective purification is usually done by mAbs adsorption to a protein A resin and after that host cell proteins, DNA, IgG aggregates and virus removal are done by two chromatography steps [99]. But these chromatography steps have some low capacity, complex scale up and high cost of resins like limitations $[99,100]$. To replace these chromatography steps by non-chromatography steps, Rosa at al. published a study which was easily scalable, capable of continuous operation and economic. A PEG - phosphate was developed for the extraction of IgG from $\mathrm{CHO}$ and PER.C6 ${ }^{\circ}$ cell supernatant. A process of extraction, back-extraction and washing were validated in a pump mixer-settler battery. Most of the impurities were removed during the extraction step. A global recovery yield of $80 \%$ and more than $99 \%$ of final protein purity from a $\mathrm{CHO}$ cell supernatant and from PER.C6 ${ }^{\circ}$ a $100 \%$ global recovery yield was observed with a promising host cell protein/ IgG ratio [99].

The reader is also referred to reference [96] for a comprehensive review of ATPE for the extraction and purification of mAbs. The authors have presented ATPE, a more economical and environmentally sustainable option as compared to currently established platforms specially protein A affinity chromatography. In this regard, with the aim of developing a non-chromatographic extraction method a hybrid process technology was investigated by 
Dhadge et al. in 2014. ATPS composed of PEG and dextran was added surface modified magnetic particles (MPs) at distinct salt concentrations. They observed that MPs coated dextran and gum Arabic expressed the lowest nonspecific interactions and binding capacity of gum Arabic coated particles was excellent when modified with aminophenyl boronic acid. Recovery yield was $92 \%$ with a protein purity of $98 \%$. MPs were also found to speed up the process of phase separation [101].

Silva et al. studied the purification of anti-CD34 in hybridoma cells by ATPS, using an integrated process that was capable to clarify and partially purify mAbs in a single step. Different ionic strengths $(0-300 \mathrm{mM} \mathrm{NaCl})$ was used to study, PEG - dextran systems at different $\mathrm{pH}$ values ( $\mathrm{pH} 3,4$ and 7). They also evaluated the effect of different MW of PEG (3350 and $600 \mathrm{Da}$ ). Results showed that ATPS composed of 7 \% PEG $6000 \mathrm{Da}, 5 \%$ dextran $500000 \mathrm{Da}$ and $150 \mathrm{mM} \mathrm{NaCl}$ at pH 3 was the best in terms of recovery yield. This system was capable of to recover $84 \pm 6.5 \%$ IgG in the PEG-rich phase with $0.1 \pm 0.2 \%$ of cells [89]. Recently, in 2015, Muendges and co-workers figured out the solubility of biological material as the most limiting factor during ATPE. Keep in view, the decreased solubility of $\mathrm{CHO}$ cell supernatant proteins in the ATPS, high MW PEG was used in previous studies. Therefore, solubility of IgG in different phase forming components was screened and the best solubility was found in an ATPS composed of PEG2000/ phosphate at $\mathrm{pH}$ six. The effect of $\mathrm{NaCl}$ was also investigated and it was observed that productive conditions were containing no or high amount of $\mathrm{NaCl}$. Moreover, they concluded that the decrease in product-phase can improve the purity to a purification factor of up to 3.1 and recovery yield more than $90 \%$ with a single step [102].

These studies suggest ATPE as an economical and environmentally stable option for the purification of monoclonal antibodies as compared to currently used protein A chromatography because of the high costs of resins, reusability limitations and formation of aggregates [96]. A selective comparison between ATPAP and protein A affinity chromatography for an almost similar recovery yield of IgG cited by Ruiz-Ruiz et al. would be worth mentioning here. Which shows the $91 \%$ recovery and > $90 \%$ purity of IgG in an ATPAP [103], and $95 \%$ recovery with $>93 \%$ purity [104] achieved by protein A affinity chromatography [6]. Although, a new generation of protein A resins has been developed with high binding capacities and high life span, but ATPE process has advantages especially when processing high titer cell culture supernatants [96].

\section{DNA and nucleic acids}

The development of molecular biology and gene therapy is also dependent on the efficient and cost-effective isolation of DNA, RNA and other nucleic acid based biomolecules. Frerix and co-workers reported such low cost, polymer - salt (PEG - potassium phosphate) for the recovery of plasmid DNA (pDNA) in combination with ultrafiltration. ATPS was composed of $15 \%$ PEG and $20 \%$ potassium phosphate and strong partitioning of pDNA was observed at $\mathrm{pH} 7.0$ [105].

A method optimized by RSM, showed the $99 \%$ recovery of pDNA from an alkaline lysate of Escherichia coli with a system composed of PEG 400 - sodium citrate, $38.7 \%$ of TLL, lysate load of $10 \%$ and phase volume ration of 1.5 [50]. The experiments of Gomes at al., [106] resulted in almost $100 \%$ recovery yield of pDNA with sodium citrate in a PEG - salt system and a lower recovery but higher purification in an ammonium sulfate based system. Finally, a mixture of $25 \%(\mathrm{w} / \mathrm{w})$ ammonium sulfate and $75 \%(w / w)$ sodium citrate offered an optimum outcome with a $91.1 \%$ recovery and $17.2 \%$ purity.

Plasmid DNA displays a varied behavior in high molecular weight (HMW) PEG and in low molecular weight (LMW) PEG. In HMW-PEG based ATPS pDNA partition towards bottom phase only while in LMW-PEG ATPS partition of all phases with respect to the composition of the phase, temperature and lysate concentration used in ATPS [107].

Scaling-up of systems is very essential for the application of ATPS in industry to purify pDNA. Easy scale up of ATPS is one of the most advantageous side of this technique. A tenfold scale up was demonstrated recently with a recovery of $97.4 \%$ of pDNA and an $86.4 \%$ depletion of RNA [108]. Isolation of polymerase chain reaction (PCR) DNA fragments generated during in vitro PCR have also been reported [109].

\section{Virus, virus like particles}

ATPS has been successfully employed for the recovery of virus, virus like particles (VLPs) or bionanoparticles however, has not been fully explored yet. Vaccine production, delivery vector for gene therapy and other applications of viruses and bionanuparticles demands high yielding downstream processing. ATPS is a very promising technique for the downstream processing of a range of biological products because of its ability to operate in a continuous mode. However, the integration of ATPS for the recovery of virus and virus to an industrial scale in still lagging because of complex partition mechanism [110].

Aqueous two-phase micellar system has been reported to be very efficient for the purification and concentration of viruses as viral particles have larger radii $(100 \AA$ to $2000 \AA$ ) than most of the proteins and according to excluded volume theory larger size protein exhibit strong partition behavior in micellar ATPSs [12].

Adenovirus was recovered from a crude lysate of HEK293 by Negrete et al., [111] using a PEG 300 - 
phosphate system, which yielded in $90 \%$ of infectious particles [106]. ATPS was also investigated for the purification of VLPs (rotavirus-like particles), results showed a recovery of $85 \%$ [112] and most recently single-stage and multi-stage ATPS has been employed for the purification of VLPs (human B19 parvo) from crude Spodoptera frugiperda $S f 9$ cell lysate. First time, a multi-stage ATPE was shown for VLPs, with satisfying results [113].

\section{Cells and organelles}

Purification of whole cell and their organelles using aqueous two phase system have been investigated by several authors. There are many reasons behind the purification of these cells and their organelles. Like, platelets contain various growth factors (e.g., plateletderived growth factor, transforming growth factor $\beta$ and vascular endothelial growth factor). Thus, platelets are used as healing stimuli in different medical conditions. In 2006, Sumida and co-workers reported the separation of platelets from whole blood using 16 types of polymers in a polymer-based ATPS. They concluded that poly (2methylacryloxyethyl phophorylcholine-co- $n$-butyl methacrylate) based separations were suitable for therapeutic purposes [114]. Separation of cells in ATPS depends on numerous intrinsic properties like, electrochemical charge, size, hydrophobic and hydrophilic surface properties [115] or in other words, interaction between the cell/organelle and polymer used in ATPS draw the separation pattern [116].

Nowadays microfluidic devices are used for the separation of blood cells, Toner and Irimia [117] excellently reviewed the use of such devices for blood cell separations. However, in 2009, for the first time a microfluidic separation method was applied to blood in an ATPS. Whole blood was exposed to PEG - dextran ATPS and the results showed a ratio of 9.13 of leukocytes to erythrocytes [118].

ATPS has also been used for several decades in plant related research. Numerous studied has been reported for the separation of whole-cell from cell lysates (e.g., isolation of plasma membrane vesicles from maize [119], purification of symbiosomes from pea [120] and selection of high yielding cells from cultured strawberry cells [121].

Extracellular vesicles such as exosomes and microvesicles are used as biomarkers for blood based diagnostic purposes. But there is a lack of effective purification strategies. Recently, in 2015, Shin et al., demonstrated an ATPS method for the purification of such extracellular vesicles. A polymer - polymer (PEG - dextran) ATPS was used which resulted in almost $70 \%$ recovery just in a time span of $15 \min$ [122].

\section{Low molecular weight compounds}

Low molecular weight biomolecules (e.g., phytochemicals and secondary metabolites) are considered as high valued products due to their broad applications in food to pharmaceutical industry [123]. In traditional extraction and separation techniques, organic solvents are widely used, which are toxic and inflammable. This problem can be solved by the help of ATPS. However, there are only few studies regarding the application of ATPS for the processing these kind of biomolecules [123, 124].

In 2007, Chethana et al., [125] investigated the extraction and purification of betalains (derivatives of betalamic acids) from Beta vulgaris. As a natural food colorant, the demand of betalains is increasing, mainly because of its antimicrobial and antiviral activities. This differential partitioning resulted in the $70-75 \%$ of betalains in top phase and sugars in bottom phase. Wu et al., showed the extraction of anthocyanins from mulberry (Morus atropurpurea Roxb.) Moreover, they stated that the ATPE did not alter the composition these natural pigments and the antioxidant activity of the extract was relatively high as compared to conventional extraction techniques [126]. Other reported studies include the recovery of crocins [127] from Crocus sativas using an ethanol-potassium phosphate ATPS and the extraction of anthocyanins [128] from Brassica oleracea L.

Recently, Zhang and his co-workers used ATPE for the extraction and enrichment of genistein and apigenin from pigeon pea roots (Cajanus cajan (L.) Millsp.). They employed an ATPS composed of $28 \%$ ethanol and $22 \%$ $\mathrm{K}_{2} \mathrm{HPO}_{4}$ and the recoveries were $93.8 \%$ and $94 \%$ for genistein and apigenin, respectively [124]. The extraction of natural products from plant matrix by ATPE is getting more importance due to increase in the demand in the nutraceutical industry.

\section{Drug residues in food and water}

ATPS is also a novel technology for the separation and enrichment of drug residues in the water [129], food of animal origin [130] and herbs [131]. ATPS has several advantages over traditional organic solvent extraction, solid phase extraction (SPE) methods. It is regarded as an environmental friendly extraction procedure as both phases of ATPS contains water and no toxic volatile organic solvent is consumed in the process [129]. Moreover, the de-emulsification step is necessary in extraction methods (e.g., SPE, disperse solid-phase extraction (DSPE), quick, easy, cheap, effective, rugged and safe (QuEChERS) and others) for the extraction of analytes in milk because of the proteins and fats interference. But in ATPS it is possible to directly extract analytes in one single step [132].

Detection of residues at lower concentration is also possible with these biphasic systems. Han et al., showed the determination of chloramphenicol residues at concentrations lower than $1.5 \mu \mathrm{g} \mathrm{kg}^{-1}$, which was not possible in previously reported, dispersive liquid-liquid 
micro-extraction (DLLME) and matrix solid-phase dispersion (MSPD) methods [130]. Pesticides and herbicide residues may also accumulate in the animal derived foods (e.g., milk). Recently, Yang and his co-workers investigated five triazines herbicides in milk using ATPE. This simple ATPS was composed of acetonitrile and $\mathrm{K}_{2} \mathrm{HPO}_{4}$. The limits of detection (LOD) were 2.1, 2.6, 2.3, 2.8 and $2.5 \mu \mathrm{g} \mathrm{L}^{-1}$ for atraton, desmetryn, atrazine, terbumeton and terbuthylazine, respectively. The average recoveries of analytes were ranging from 86.3 to $120.6 \%$ [132].

Roxithromycin (ROX) is a semi-synthetic antibiotic used frequently in human and veterinary medicine. Li et al. [129] reported the extraction of ROX residues in aqueous environment and proved that IL-base ATPS more efficient than traditional solvent extraction for ROX and other hydrophobic antibiotics. Table 2 is a compilation of studies reported so far, using ATPS for the extraction of drug residues in water and foods of animal origin.

\section{Metals and metal ions}

ATPS is regarded as the most promising system also for the separation of metals and metal ions because of water being a major system constituent and the use of other non-inflammable and non-toxic constituents [4, 132, 134]. First paper regarding the partition of metal ions was published in 1984 by Zvarova and his co-workers [135]. In 1993, Roger et al. [136] published a review about separations of metal ions in ATPS and cited these early studies coming from Russian laboratories. Later, they investigated the effect of different factors (e.g., temperature and composition of ATPS) on the partition behavior of metal ions [34, 137-139]. Guzmán and Téllez reviewed the models involved in the affinity partitioning of metal ions, chapter is included in the book edited by Rogers and Eiteman [34].

Unlike the biomolecule partition, in which a wide range compounds was used for the formation of ATPS, most of the studies on metal partitioning show the ATPS formed by poly (ethylene oxide) (POE) and inorganic anions [134]. The discovery of triblock-copolymer opened new opportunities for metal extraction using ATPS. Triblock-copolymer such as $(\mathrm{EO})_{x}(\mathrm{PO})_{y}(\mathrm{EO})_{x}$ aggregates in an aqueous solution at critical temperature and concentration. Micelles formed in the process of aggregation contain hydrophobic units like poly (propylene oxide) (PPO) at the core surrounded by hydrophilic units such

Table 2 Extraction of drug residues in water and foods of animal origin using ATPS

\begin{tabular}{|c|c|c|c|c|c|c|c|}
\hline Sample & Drug & ATPS & Detection limit & $\begin{array}{l}\text { Average Extraction } \\
\text { Efficiency }(\%)\end{array}$ & Recovery (\%) & $\begin{array}{l}\text { Linear Range } \\
\left(\mu \mathrm{g} \mathrm{m} L^{-1}\right)\end{array}$ & Ref. \\
\hline Water & Roxithromycin & $\begin{array}{l}\text { 1-butyl-3-methylimidazolium } \\
\text { tetrafluoraborate }-\mathrm{Na}_{2} \mathrm{CO}_{3} \\
\text { (IL - salt) }\end{array}$ & $0.03 \mu \mathrm{g} \mathrm{mL}^{-1}$ & 90.7 & $90.0-90.8$ & $1.00-20.00 \mu \mathrm{g} \mathrm{mL}^{-1}$ & {$[129]$} \\
\hline Water & Sulfamethoxazole & $\begin{array}{l}\text { Poly (propylene glycol) }{ }_{400}- \\
\mathrm{NaH}_{2} \mathrm{PO}_{4} \text { (polymer - salt) }\end{array}$ & $0.1 \mu \mathrm{g} \mathrm{L}^{-1}$ & 99.2 & $96.0-100.6$ & $2.5-250.0 \mu \mathrm{g} \mathrm{L}^{-1}$ & [169] \\
\hline Lake Water & \multirow[t]{4}{*}{ Chloramphenicol } & \multirow{4}{*}{$\begin{array}{l}\text { 1-butyl-3-methylimidazolium } \\
\text { chloride - } \mathrm{K}_{2} \mathrm{HPO}_{4}(\mathrm{IL}-\text { salt })\end{array}$} & \multirow[t]{4}{*}{$0.1 \mathrm{ng} \mathrm{mL}^{-1}$} & \multirow[t]{4}{*}{98.5} & \multirow[t]{4}{*}{$97.1-101.9$} & \multirow[t]{4}{*}{$0.5-500 \mathrm{ng} \mathrm{mL}^{-1}$} & \multirow[t]{4}{*}[170]{} \\
\hline Feed Water & & & & & & & \\
\hline Milk & & & & & & & \\
\hline Honey & & & & & & & \\
\hline Feed Water & \multirow[t]{3}{*}{ Chloramphenicol } & \multirow{3}{*}{$\begin{array}{l}\text { 1-butyl-3-methylimidazolium } \\
\text { tetrafluoraborate }-\mathrm{Na}_{3} \mathrm{C}_{6} \mathrm{H}_{5} \mathrm{O}_{7} \\
(\mathrm{~L} \mathrm{~L} \text { - salt) }\end{array}$} & \multirow[t]{3}{*}{$0.3 \mathrm{ng} \mathrm{mL}^{-1}$} & \multirow[t]{3}{*}{90.1} & \multirow[t]{3}{*}{$90.4-102.7$} & \multirow[t]{3}{*}{$2-1000 \mathrm{ng} \mathrm{mL}^{-1}$} & \multirow[t]{3}{*}{ [130] } \\
\hline Milk & & & & & & & \\
\hline Honey & & & & & & & \\
\hline Milk & \multirow[t]{3}{*}{ Ciprofloxacin } & \multirow{3}{*}{$\begin{array}{l}\text { Poly (ethylene glycol-ran- } \\
\text { propylene glycol) EOPOL31 - } \\
\mathrm{K}_{2} \mathrm{HPO}_{4} \text { (polymer - salt) }\end{array}$} & \multirow[t]{3}{*}{$6.8 \mathrm{ng} \mathrm{g}^{-1}$} & $1 \mathrm{st}=97.7$ & $1 \mathrm{st}=83.5-90.2$ & \multirow[t]{3}{*}{ - } & \multirow[t]{3}{*}{ [171] } \\
\hline Egg & & & & $2 \mathrm{nd}=85.6$ & $2 \mathrm{nd}=83.8-86.8$ & & \\
\hline Shrimp & & & & & & & \\
\hline Milk & Sulfonamides & $\begin{array}{l}\text { 1-butyl-3-methylimidazolium } \\
\text { tetrafluoraborate - } \\
\mathrm{C}_{6} \mathrm{H}_{5} \mathrm{Na}_{3} \mathrm{O} 7.2 \mathrm{H}_{2} \mathrm{O} \text { (IL - salt) }\end{array}$ & $2.04-2.84 \mathrm{ng} \mathrm{mL}^{-1}$ & - & $72.32-108.96$ & $\begin{array}{l}8.55-1036.36 \\
\mathrm{ng} \mathrm{mL}\end{array}$ & {$[172]$} \\
\hline \multirow[t]{3}{*}{ Honey } & Tetracycline (TC) & \multirow{3}{*}{$\begin{array}{l}\text { 1-octyl-3-methylimidazolium } \\
\text { bromide - sodium dodecyl } \\
\text { sulfate (SDS) }\end{array}$} & $\mathrm{TC}=5.8$ & \multirow[t]{3}{*}{-} & \multirow[t]{3}{*}{$85.5-110.9$} & $\mathrm{TC}=20.1-301.2$ & \multirow[t]{3}{*}{ [173] } \\
\hline & $\begin{array}{l}\text { Oxytetracycline } \\
\text { (OTC) }\end{array}$ & & $\mathrm{OTC}=8.2$ & & & $\mathrm{OTC}=30.3-303.6$ & \\
\hline & $\begin{array}{l}\text { Chloramphenicol } \\
\text { (CAP) }\end{array}$ & & $\mathrm{CAP}=4.2 \mu \mathrm{g} \mathrm{kg}^{-1}$ & & & $\begin{array}{l}\text { CAP }=20.4-305.4 \\
\mu \mathrm{kg}^{-1}\end{array}$ & \\
\hline Shrimp & Chloramphenicol & $\begin{array}{l}\text { Polyoxyethylene lauryl ether } \\
\text { (POELE10) - } \mathrm{NaH}_{2} \mathrm{PO}_{4} \\
\text { (polymer - salt) }\end{array}$ & $0.8 \mu \mathrm{g} \mathrm{kg}^{-1}$ & 99.42 & $98-100.4$ & $0.5-3.00 \mu \mathrm{g} \mathrm{kg}^{-1}$ & {$[174]$} \\
\hline
\end{tabular}


as POE. These cores have the potential to solubilize the water insoluble agents and its hydrophobic metallic complexes [140]. Triblock-copolymer based ATPSs have been reported for the extraction and separation different metal and metal ions [133-135, 141, 142].

IL-based ATPSs are considered as the most "green" ATPS because of their properties of low volatility, nonflammability, strong solubility and large liquid range. Few studies have been reported regarding metal extraction employing IL-ATPS. Zheng et al., used an ATPS containing 1-hexyl-3-methyl imidazole dodecyl sulfonate and PEG6000 for the extraction of gold (III). They concluded ATPS as a promising technique for the extraction and separation of gold (III) [143]. Other studies include the separation of cadmium [144] and extraction of chromium [145] using ILATPS.

\section{Extractive fermentation}

Extractive fermentation or in situ product recovery is the process in which ATPS is integrated with bioconversion to overcome the low product yield [146]. Low productivity is one of the most commonly observed issue in biotechnological processes because of inhibition, toxicity and instability of the end-product [4]. Therefore, about 60-90\% cost of a biological process is expended in downstream processing [147]. However, a high end-product concentration is feasible by extractive fermentation, because of low interfacial tension, continuous mode, selective separation and biocompatibility of ATPS $[4,147]$.

This strategy involves the continuous removal of product from its site of production/fermentation broth to the opposite phase simultaneously during production $[26,146]$. Thus, the product of interest can be extracted from the system in a single step without performing biomass recovery or cell disruption [148]. A list of selected recent extractive fermentation studies using ATPS has been presented in Table 3 .

\section{Environmental remediation}

The applications of ATPS are not only limited to biotechnology, but also being extended to environmental remediation in various ways $[4,7]$.

Textile industry is responsible for the discharge of 10 $15 \%$ of annually produced 1 million tons of biodegradable resistant dyes. These dyes and their metabolites are toxic and carcinogenic in nature, thus posing a highly potential danger to aquatic biota and human health $[149,150]$. Different physical and chemical methods have been studied for the removal of dyes from wastewaters. However, most of these methods are high cost, low efficient and laborious [151]. But these drawbacks could be overcome by ATPS which is an economic and eco-friendly method for the removal of textile dyes [152, 153]. Recently, Ferreira and coworkers [149] studied the IL-based ATPS for the extraction of a set of dyes in textile effluents and Ivetic et al. [150] investigated a PEG - salt ATPS model for Acid blue 9. Results showed ATPS as an excellent alternative dye removal method with high yield.

Hatti-Kaul [4, 7] cited Ström et al., [154] for large scale removal of microorganism from cutting fluids by using ATPS and demonstrated to be more effective than biocide treatment and irradiation. Other examples include the removal of metal ions [139], food coloring dyes [155, 156] aromatics from industrial and environmental settings [157].

\section{Other applications}

ATPS has been most commonly used for the separation of macromolecules, however, it can also be employed as an analytical tool. The analytical applications (e.g., understanding chemical properties and behavior of protein, etc.) of ATPS are possible because the distribution between phases depends on system variation instead of the distribution of small molecules [4]. Or simply, partitioning in ATPS is sensitive to surface properties and conformation of phase forming component and particulate material [7]. According to Grilo et al. [1], ATPS is gaining interest as an analytical tool and $8 \%$ of total application articles published in 2013 (ISI-indexed) account for analytical applications.

ATPS has been used with devices (column contactors) for continuous processes and microfluidics devices for the fractionation of biomolecules [9, 117, 118]. Moreover, ATPS can also be integrated with other separation techniques such as solvent sublation, which is termed as aqueous two-phase flotation [85, 158]. ATPS has also been successfully integrated with centrifugal partition chromatography $(\mathrm{CPC})$ for the separation of biomolecules $[150,159]$.

Table 3 A list of selected recent extractive fermentation using ATPS

\begin{tabular}{|c|c|c|c|}
\hline Product & ATPS & Organism & Ref. \\
\hline Lipase & $10 \%$ EOPO & Burkholderia cepacia & {$[175]$} \\
\hline Clavulanic acid & $25 \%(w / w)$ PEG8000 - phosphate salts & Streptomyces DAUFPE 3060 & {$[176]$} \\
\hline Lipase & $9.6 \%$ (w/w) PEG8000 - $1.0 \%$ (w/w) Dextran T500 & Burkholderia pseudomallei & [177] \\
\hline Alkaline phosphatase & $9.0 \%(w / v)$ PEG4000 - $9.6 \%(w / v)$ Dextran T500 & Bacillus lincheniformis MTCC 1483 & [178] \\
\hline$\beta$-carotene, Lutein & $\begin{array}{l}6.6 \%(\mathrm{w} / \mathrm{w}) \text { PEG3350 - } 8.4 \% \text { (w/w) Dextran } 66900 \text { And } \\
4.22 \%(\mathrm{w} / \mathrm{w}) \text { PEG8000 - } 9.77 \%(\mathrm{w} / \mathrm{w}) \text { Dextran } 66900\end{array}$ & Synechocystis sp. PCC 6803 & [148] \\
\hline
\end{tabular}


Proteomics tools such as two dimensional electrophoresis (2DE) are being used with ATPS for the physicochemical characterization of biological samples, which is called as three dimensional (3D) proteomic analysis [160]. The combination of ATPS and dielectrophoresis offers a powerful separation and enrichment technique in which bio-particles are separated by ATPS and then concentrated by dielectrophoresis [160].

\section{Conclusion and future trends}

ATPS is a simple, selective and low cost promising separation technique. Easy scalability of this technique makes it valid to be adopted by industries for downstream processing. However, it has been not widely used at commercial scale. The reasons behind this reluctance could be so many, but the poor understanding of the partition mechanism involved in the ATPS will always be on top. No doubt, the investigation and sorting out of the partition mechanisms governing ATPS will lead to a revolution in separation science. New types of ATPSs and more knowledge about phase forming components would result in more advance applications. Integration of ATPS with other promising tools will also be a breakthrough for recovering high value products.

\section{Abbreviations}

2DE: Two dimensional electrophoresis; 3D: Three dimensional; ANOVA: Analysis of variance; ATPAP: Aqueous two-phase affinity partitioning; ATPE: Aqueous two-phase extraction; ATPS: Aqueous two-phase system; BBD: Box-Behken design; BmimCl: Butyl-3-methylimidazolium chloride; BSA: Bovine serum albumin; CCD: Central composite design; CHO: Chinese hamster ovary; CPC: Centrifugal partition chromatography; DES: Deep eutectic solvent; DLLME: Dispersive liquid-liquid micro-extraction; DoE: Design of Experiments; DSPE: Disperse solid-phase extraction; EOPO: Ethylene oxide and propylene oxide; FDA: Food and Drug Administration; fFD: Fractional factorial design; FFD: Full factorial design; FITC: Fluorescein isothiocyanate; HIC: Hydrophobic interaction chromatography; HPLC: High performance liquid chromatography; ILs: Ionic liquids; LLE: Liquid-liquid extraction; LOD: Limits of detection; mAbs: Monoclonal antibodies; MPs: Magnetic particles; MSPD: Matrix solidphase dispersion; MW: Molecular weight; OFAT: One-factor/variable-at-a-time; PBD: Plackett-Burman design; PCR: Polymerase chain reaction; pDNA: Plasmid DNA; PEG: Polyethylene glycol; pl: Isoelectric point; QuEChERS: Quick, easy, cheap, effective, rugged and safe; ROX: Roxithromycin; RSM: Response surface methodology; SEC: Size-exclusion chromatography; SPE: Solid phase extraction; STL: Slope of tie line; TEG-COOH: Triethylene glycol diglutaric acid; TLL: Tie line length; VLPS: Virus like particles

\section{Funding}

Ministry of Agriculture the People's Republic of China (2011BAK10B07-5). Risk assessment of quality and safety of livestock and poultry products (GJFP2016008). Huazhong Agricultural University, Independent Technology Innovation Fund Projects (Item \# 2662015PY021).

\section{Authors' contributions}

$Y Z, A S, M S, H H$ and SA carried out the literature mining. SX, DC, XW, LH and DP designed, MI and YT wrote the review. ZY reviewed and edited the manuscript. All authors read and approved the final manuscript.

\section{Competing interests}

The authors declare that they have no competing interests.

\section{Author details}

${ }^{1}$ National Reference Laboratory of Veterinary Drug Residues (HZAU)/MOA Key Laboratory of Food Safety Evaluation, Huazhong Agricultural University, Wuhan, Hubei 430070, China. ${ }^{2}$ MAO Laboratory for Risk Assessment of Quality and Safety of Livestock and Poultry Products, Huazhong Agricultural University, Wuhan, Hubei 430070, China.

Received: 2 July 2016 Accepted: 26 September 2016

Published online: 28 October 2016

\section{References}

1. Grilo AL, Raquel Aires-Barros M, Azevedo AM. Partitioning in aqueous two-phase systems: fundamentals, applications and trends. Sep Purif Rev. 2016;45:68-80.

2. Van Berlo M, Luyben KCA, van der Wielen LA. Poly (ethylene glycol)-salt aqueous two-phase systems with easily recyclable volatile salts. J Chromatogr B. 1998;711:61-8.

3. Albertsson PA. Partition of Cell Particles and Macromolecules. Hoboken: Wiley Intersciences; 1986.

4. Hatti-Kaul R. Aqueous Two-Phase Systems: Methods and Protocols. Berlin: Springer Science \& Business Media; 2000.

5. Asenjo JA, Andrews BA. Aqueous two-phase systems for protein separation: a perspective. J Chromatogr A. 2011;1218:8826-35

6. Ruiz-Ruiz F, Benavides J, Aguilar O, Rito-Palomares M. Aqueous two-phase affinity partitioning systems: current applications and trends. J Chromatogr A. 2012;1244:1-13.

7. Hatti-Kaul R. Aqueous two-phase systems. Mol Biotechnol. 2001;19:269-77.

8. Walter H. Partitioning in Aqueous Two-Phase System: Theory, Methods, Uses, And Applications To Biotechnology. Amsterdam: Elsevier; 2012.

9. Espitia-Saloma E, Vázquez-Villegas P, Aguilar O, Rito-Palomares M. Continuous aqueous two-phase systems devices for the recovery of biological products. Food Bioprod Process. 2014;92:101-12.

10. Asenjo JA, Andrews BA. Aqueous two-phase systems for protein separation: phase separation and applications. J Chromatogr A. 2012;1238:1-10.

11. Molino JVD, Marques V, de Araújo D, Júnior AP, Mazzola PG, Gatti MSV. Different types of aqueous two-phase systems for biomolecule and bioparticle extraction and purification. Biotechnol Progr. 2013;29:1343-53.

12. Liu C, Kamei DT, King JA, Wang DI, Blankschtein D. Separation of proteins and viruses using two-phase aqueous micellar systems. J Chromatogr B. 1998;711:127-38.

13. Xiao JX, Sivars $U$, Tjerneld F. Phase behavior and protein partitioning in aqueous two-phase systems of cationic-anionic surfactant mixtures. J Chromatogr B. 2000;743:327-38.

14. Albertsson PÅ. Fractionation of particles and macromolecules in aqueous two-phase systems. Biochem Pharmacol. 1961;5:351-8.

15. Louwrier A. Model phase separations of proteins using aqueous/ethanol components. Biotechnol Tech. 1998;12:363-5.

16. Jiang B, Li Z-G, Dai J-Y, Zhang D-J, Xiu Z-L. Aqueous two-phase extraction of 2,3-butanediol from fermentation broths using an ethanol/phosphate system. Process Biochem. 2009:44:112-7.

17. Bordier C. Phase separation of integral membrane proteins in Triton X-114 solution. J Biol Chem. 1981;256:1604-7.

18. Lye GJ, Asenjo JA, Pyle DL. Extraction of lysozyme and ribonuclease-a using reverse micelles: Limits to protein solubilization. Biotechnol Bioeng. 1995;47:509-19.

19. Berthod A, Ruiz-Angel MJ, Carda-Broch S. Ionic liquids in separation techniques. J Chromatogr A. 2008;1184:6-18.

20. Johansson H-O, Persson J, Tjerneld F. Thermoseparating water/polymer system: A novel one-polymer aqueous two-phase system for protein purification. Biotechnol Bioeng. 1999;66:247-57.

21. Zafarani-Moattar MT, Hamzehzadeh S, Nasiri S. A new aqueous biphasic system containing polypropylene glycol and a water-miscible ionic liquid. Biotechnol Progr. 2012;28:146-56.

22. Harris EL, Angal S. Protein Purification Methods. Oxford: IRL Press at Oxford University Press; 1989.

23. Mazzola PG, Lopes AM, Hasmann FA, Jozala AF, Penna TC, Magalhaes PO, RangelYagui CO, Pessoa Jr A. Liquid-liquid extraction of biomolecules: an overview and update of the main techniques. J Chem Technol Biot. 2008;83:143-57.

24. Salamanca M, Merchuk J, Andrews B, Asenjo J. On the kinetics of phase separation in aqueous two-phase systems. J Chromatogr B. 1998;711:319-29.

25. Perez B, Malpiedi LP, Tubío G, Nerli B, de Alcântara Pessôa Filho P. Experimental determination and thermodynamic modeling of phase equilibrium and protein partitioning in aqueous two-phase systems containing biodegradable salts. J Chem Thermodyn. 2013;56:136-43. 
26. Raja S, Murty VR, Thivaharan V, Rajasekar V, Ramesh V. Aqueous two phase systems for the recovery of biomolecules-a review. Sci Technol. 2011;1:7-16.

27. Walter H, Johansson G. Aqueous Two-Phase Systems. Berlin: Elsevier; 1994.

28. Wu Y-T, Lin D-Q, Zhu Z-Q. Thermodynamics of aqueous two-phase systems - the effect of polymer molecular weight on liquid-liquid equilibrium phase diagrams by the modified NRTL model. Fluid Phase Equilib. 1998;147:25-43.

29. Diamond AD, Hsu JT. Correlation of protein partitioning in aqueous polymer two-phase systems. J Chromatogr A. 1990;513:137-43.

30. Baskir JN, Hatton TA, Suter UW. Thermodynamics of the separation of biomaterials in two-phase aqueous polymer systems: effect of the phaseforming polymers. Macromolecules. 1987;20:1300-11.

31. Diamond AD, Hsu JT. Fundamental studies of biomolecule partitioning in aqueous two-phase systems. Biotechnol Bioeng. 1989;34:1000-14.

32. Eiteman MA, Gainer JL. A model for the prediction of partition coefficients in aqueous two-phase systems. Bioseparation. 1991;2:31.

33. Cabezas $\mathrm{H}$. Theory of phase formation in aqueous two-phase systems. J Chromatogr B. 1996;680:3-30.

34. Rogers RD, Eiteman MA. Aqueous Biphasic Separations. Berlin: Springer; 1995.

35. Andrews BA, Asenjo JA. Theoretical and experimental evaluation of hydrophobicity of proteins to predict their partitioning behavior in aqueous two phase systems: a review. Sep Sci Technol. 2010;45:2165-70.

36. Hachem F, Andrews B, Asenjo J. Hydrophobic partitioning of proteins in aqueous two-phase systems. Enzyme Microb Technol. 1996;19:507-17.

37. Zaslavsky BY. Aqueous two-phase partitioning: physical chemistry and bioanalytical applications. Boca Raton: CRC Press; 1994.

38. Ahuja S. Handbook of Bioseparations. Cambridge: Academic; 2000.

39. Fisher D. Separations using aqueous phase systems: applications in cell biology and biotechnology. Berlin: Springer Science \& Business Media; 2012.

40. Andrews BA, Schmidt AS, Asenjo JA. Correlation for the partition behavior of proteins in aqueous two-phase systems: effect of surface hydrophobicity and charge. Biotechnol Bioeng. 2005;90:380-90.

41. Schmidt AS, Andrews BA, Asenjo JA. Correlations for the partition behavior of proteins in aqueous two-phase systems: effect of overall protein concentration. Biotechnol Bioeng. 1996;50:617-26.

42. Cote J, Sson O. Effects of salts on the partition of proteins in aqueous polymeric biphasic systems. Acta Chem Scand B. 1974;28:873-82.

43. Olivera-Nappa A, Lagomarsino G, Andrews BA, Asenjo JA. Effect of electrostatic energy on partitioning of proteins in aqueous two-phase systems. J Chromatogr B. 2004;807:81-6.

44. Glyk A, Solle D, Scheper T, Beutel S. Optimization of PEG-salt aqueous twophase systems by design of experiments. Chemometr Intell Lab. 2015;149: $12-21$.

45. Montgomery DC. Design and Analysis of Experiments. Hoboken: Wiley; 2012.

46. Raja S, Murty VR. Optimization of aqueous two-phase systems for the recovery of soluble proteins from tannery wastewater using response surface methodology. J Eng. 2013;2013:1-10.

47. Rosa PAJ, Azevedo AM, Aires-Barros MR. Application of central composite design to the optimisation of aqueous two-phase extraction of human antibodies. J Chromatogr A. 2007;1141:50-60.

48. Selber K, Nellen F, Steffen B, Thömmes J, Kula MR. Investigation of mathematical methods for efficient optimisation of aqueous two-phase extraction. J Chromatogr B. 2000;743:21-30.

49. Box GEP, Wilson KB. On the Experimental Attainment of Optimum Conditions. J Roy Stat Soc B Met. 1951;13:1-45.

50. Rahimpour F, Feyzi F, Maghsoudi S, Hatti-Kaul R. Purification of plasmid DNA with polymer-salt aqueous two-phase system: optimization using response surface methodology. Biotechnol Bioeng. 2006;95:627-37.

51. Eriksson L. Design of Experiments: Principles and Applications. Umea: MKS Umetrics AB; 2008.

52. Valipour M. Long-term runoff study using SAMIRA and ARIMA models in United States. Mateorol Appl. 2015;22:592-8.

53. Valipour M. Critical areas of Iran for agriculture water management according to the annual rainfall. Eur J Sci Res. 2012;84:600-8.

54. Valipour M. Sprinkle and trickle irrigation system design using tapered pipes for pressure loss adjusting. J Agric Sci. 2012;4:125.

55. Valipour M. Optimization of neural networks for precipitation analysis in a humid region to detect drought and wet year alarms. Mateorol Appl. 2016;23:91-100.

56. Valipour M, Banihabib ME, Behbahani SMR. Comparison of the ARMA, ARIMA, and the autoregressive artificial neural network model in forecasting the monthly inflow of Dez dam reservoir. J Hydrol. 2013;476:433-41.
57. Xu Y, He G, Li J-J. Effective extraction of elastase from Bacillus sp. fermentation broth using aqueous two-phase system. J Zhejiang Univ Sci B. 2005;6:1087

58. Silva M, Franco T. Liquid-liquid extraction of biomolecules in downstream processing-a review paper. Braz J Chem Eng. 2000;17:1-17.

59. Carlson A. Factors influencing the use of aqueous two-phase partition for protein purification. Sep Sci Technol. 1988;23:785-817.

60. Cascone O, Andrews B, Asenjo J. Partitioning and purification of thaumatin in aqueous two-phase systems. Enzyme Microb Technol. 1991;13:629-35.

61. Diamond AD, Hsu JT. Protein partitioning in PEG/dextran aqueous twophase systems. AlChE J. 1990;36:1017-24.

62. Franco T, Andrews A, Asenjo J. Use of chemically modified proteins to study the effect of a single protein property on partitioning in aqueous twophase systems: effect of surface charge. Biotechnol Bioeng. 1996;49:309-15.

63. De Belval S, le Breton B, Huddleston J, Lyddiatt A. Influence of temperature upon protein partitioning in poly (ethylene glycol)-salt aqueous two-phase systems close to the critical point with some observations relevant to the partitioning of particles. J Chromatogr B. 1998;711:19-29.

64. Kresheck GC, Wang Z. A new micellar aqueous two-phase partitioning system (ATPS) for the separation of proteins. J Chromatogr B. 2007;858:247-53.

65. Merchuk JC, Andrews BA, Asenjo JA. Aqueous two-phase systems for protein separation. Studies on phase inversion. J Chromatogr B. 1998;711: 285-93.

66. Fan W, Glatz CE. Charged protein partitioning in aqueous polyethylene glycoldextran two-phase systems: salt effects. Sep Sci Technol. 1999;34:423-38.

67. Alves JG, Chumpitaz LD, da Silva LH, Franco TT, Meirelles AJ. Partitioning of whey proteins, bovine serum albumin and porcine insulin in aqueous twophase systems. J Chromatogr B. 2000;743:235-9.

68. Gu Z, Glatz CE. Aqueous two-phase extraction for protein recovery from corn extracts. J Chromatogr B. 2007;845:38-50

69. Balasubramaniam D, Wilkinson C, Van Cott K, Zhang C. Tobacco protein separation by aqueous two-phase extraction. J Chromatogr A. 2003;989: 119-29.

70. Ferreira GB, Evangelista AF, Junior S, Baptista J, de Souza RR, Santana JCC Tambourgi EB, Jordão E. Partitioning optimization of proteins from Zea mays malt in ATPS PEG 6000/CaCl2. Braz Arch Bio Technol. 2007;50:557-64.

71. Shihabi Z, Konen J, O'connor M. Albuminuria vs urinary total protein for detecting chronic renal disorders. Clin Chem. 1991;37:621-4.

72. Du Z, Yu Y-L, Wang J-H. Extraction of proteins from biological fluids by use of an ionic liquid/aqueous two-phase system. Chem Eur J. 2007;13: 2130-7.

73. Pei Y, Wang J, Wu K, Xuan X, Lu X. Ionic liquid-based aqueous two-phase extraction of selected proteins. Sep Purif Technol. 2009;64:288-95.

74. Saravanan S, Rao JR, Nair BU, Ramasami T. Aqueous two-phase poly (ethylene glycol)-poly (acrylic acid) system for protein partitioning: influence of molecular weight, pH and temperature. Process Biochem. 2008;43:905-11.

75. Fischer I, Franzreb M. Nanoparticle mediated protein separation in aqueous micellar two-phase systems. Solvent Extr Ion Exc. 2012;30:1-16.

76. Fischer I, Hsu C-C, Gärtner M, Müller C, Overton TW, Thomas OR, Franzreb M. Continuous protein purification using functionalized magnetic nanoparticles in aqueous micellar two-phase systems. J Chromatogr A. 2013;1305:7-16

77. Bezold F, Goll J, Minceva M. Study of the applicability of non-conventional aqueous two-phase systems in counter-current and centrifugal partition chromatography. J Chromatogr A. 2015;1388:126-32.

78. Li N, Wang Y, Xu K, Huang Y, Wen Q, Ding X. Development of green betaine-based deep eutectic solvent aqueous two-phase system for the extraction of protein. Talanta. 2016;152:23-32.

79. Saxena R, Sheoran A, Giri B, Davidson WS. Purification strategies for microbial lipases. J Microbiol Methods. 2003;52:1-18.

80. Ramakrishnan V, Goveas LC, Suralikerimath N, Jampani C, Halami PM, Narayan B. Extraction and purification of lipase from Enterococcus faecium MTCC5695 by PEG/phosphate aqueous-two phase system (ATPS) and its biochemical characterization. Biocatal Agric Biotechnol. 2016;6:19-27.

81. Rahimpour F, Hatti-Kaul R, Mamo G. Response surface methodology and artificial neural network modelling of an aqueous two-phase system for purification of a recombinant alkaline active xylanase. Process Biochem. 2016;51:452-62.

82. Li S, Cao X. Enzymatic synthesis of Cephalexin in recyclable aqueous twophase systems composed by two $\mathrm{pH}$ responsive polymers. Biochem Eng J. 2014;90:301-6. 
83. Rajagopalu D, Show PL, Tan YS, Muniandy S, Sabaratnam V, Ling TC. Recovery of laccase from processed Hericium erinaceus (Bull.: Fr) Pers. fruiting bodies in aqueous two-phase system. J Biosci Bioeng. 2016. doi:10. 1016/j.jbiosc.2016.01.016

84. Madhusudhan M, Raghavarao K, Nene S. Integrated process for extraction and purification of alcohol dehydrogenase from Baker's yeast involving precipitation and aqueous two phase extraction. Biochem Eng J. 2008;38: 414-20.

85. Show P-L, Ling T-C, Lan C-WJ, Tey B-T, Ramanan RN, Yong S-T, Ooi C-W. Review of microbial lipase purification using aqueous two-phase systems. Curr Org Chem. 2015;19:19-29.

86. Mamo G, Hatti-Kaul R, Mattiasson B. A thermostable alkaline active endo- $\beta$ 1-4-xylanase from Bacillus halodurans 57: purification and characterization. Enzyme Microb Technol. 2006;39:1492-8.

87. Igarashi L, Kieckbusch T, Franco T. Mass transfer in aqueous two-phases system packed column. J Chromatogr B. 2004;807:75-80

88. Rosa P, Azevedo A, Ferreira I, De Vries J, Korporaal R, Verhoef H, Visser T, Aires-Barros M. Affinity partitioning of human antibodies in aqueous twophase systems. J Chromatogr A. 2007;1162:103-13.

89. Silva MF, Fernandes-Platzgummer A, Aires-Barros MR, Azevedo AM. Integrated purification of monoclonal antibodies directly from cell culture medium with aqueous two-phase systems. Sep Purif Technol. 2014; 132:330-5.

90. Rosa P, Azevedo A, Sommerfeld S, Mutter M, Aires-Barros M, Bäcker W. Application of aqueous two-phase systems to antibody purification: a multistage approach. J Biotechnol. 2009;139:306-13.

91. Azevedo AM, Rosa PAJ, Ferreira IF, Aires-Barros MR. Chromatography-free recovery of biopharmaceuticals through aqueous two-phase processing. Trends Biotechnol. 2009;27:240-7.

92. Sulk B, Birkenmeier G, Kopperschläger G. Application of phase partitioning and thiophilic adsorption chromatography to the purification of monoclonal antibodies from cell culture fluid. J Immunol Methods. 1992;149:165-71.

93. Azevedo AM, Rosa PA, Ferreira IF, Aires-Barros MR. Optimisation of aqueous two-phase extraction of human antibodies. J Biotechnol. 2007;132:209-17.

94. Rosa P, Azevedo A, Ferreira I, Sommerfeld S, Bäcker W, Aires-Barros M. Downstream processing of antibodies: single-stage versus multi-stage aqueous two-phase extraction. J Chromatogr A. 2009;1216:8741-9.

95. Azevedo A, Rosa P, Ferreira I, Aires-Barros M. Integrated process for the purification of antibodies combining aqueous two-phase extraction, hydrophobic interaction chromatography and size-exclusion chromatography. J Chromatogr A. 2008;1213:154-61.

96. Rosa P, Azevedo A, Sommerfeld S, Bäcker W, Aires-Barros M. Aqueous twophase extraction as a platform in the biomanufacturing industry: economical and environmental sustainability. Biotechnol Adv. 2011;29:559-67.

97. Rosa P, Azevedo A, Sommerfeld S, Bäcker W, Aires-Barros M. Continuous aqueous two-phase extraction of human antibodies using a packed column. J Chromatogr B. 2012;880:148-56.

98. Silva DFC, Azevedo AM, Fernandes P, Chu V, Conde JP, Aires-Barros MR. Design of a microfluidic platform for monoclonal antibody extraction using an aqueous two-phase system. J Chromatogr A. 2012;1249:1-7.

99. Rosa PA, Azevedo AM, Sommerfeld S, Mutter M, Bäcker W, Aires-Barros MR. Continuous purification of antibodies from cell culture supernatant with aqueous two-phase systems: from concept to process. Biotech J. 2013;8:352-62.

100. Hober S, Nord K, Linhult M. Protein A chromatography for antibody purification. J Chromatogr B. 2007;848:40-7.

101. Dhadge VL, Rosa SA, Azevedo A, Aires-Barros R, Roque AC. Magnetic aqueous two phase fishing: a hybrid process technology for antibody purification. J Chromatogr A. 2014;1339:59-64.

102. Muendges J, Stark I, Mohammad S, Górak A, Zeiner T. Single stage aqueous two-phase extraction for monoclonal antibody purification from cell supernatant. Fluid Phase Equilib. 2015;385:227-36.

103. Azevedo A, Rosa P, Ferreira I, Pisco A, De Vries J, Korporaal R, Visser T, AiresBarros M. Affinity-enhanced purification of human antibodies by aqueous two-phase extraction. Sep Purif Technol. 2009;65:31-9.

104. Yang H, Gurgel PV, Carbonell RG. Purification of human immunoglobulin G via FC-specific small peptide ligand affinity chromatography. J Chromatogr A. 2009;1216:910-8.

105. Frerix A, Müller M, Kula M-R, Hubbuch J. Scalable recovery of plasmid DNA based on aqueous two-phase separation. Biotechnol Appl Biochem. 2005; 42:57-66.
106. Gomes GA, Azevedo AM, Aires-Barros MR, Prazeres DMF. Purification of plasmid DNA with aqueous two phase systems of PEG 600 and sodium citrate/ammonium sulfate. Sep Purif Technol. 2009;65:22-30.

107. Luechau F, Ling TC, Lyddiatt A. Partition of plasmid DNA in polymer-salt aqueous two-phase systems. Sep Purif Technol. 2009;66:397-404.

108. Wiendahl M, Oelmeier SA, Dismer F, Hubbuch J. High-throughput screening-based selection and scale-up of aqueous two-phase systems for pDNA purification. J Sep Sci. 2012;35:3197-207.

109. Matos T, Johansson H-O, Queiroz JA, Bulow L. Isolation of PCR DNA fragments using aqueous two-phase systems. Sep Purif Technol. 2014;122:144-8.

110. Nestola P, Peixoto C, Silva RR, Alves PM, Mota JP, Carrondo MJ. Improved virus purification processes for vaccines and gene therapy. Biotechnol Bioeng. 2015;112:843-57.

111. Negrete A, Ling TC, Lyddiatt A. Production of adenoviral vectors and its recovery. Process Biochem. 2007;42:1107-13.

112. Benavides J, Mena JA, Cisneros-Ruiz M, Ramírez OT, Palomares LA, RitoPalomares M. Rotavirus-like particles primary recovery from insect cells in aqueous two-phase systems. J Chromatogr B. 2006;842:48-57.

113. Effio $C L$, Wenger L, Ötes O, Oelmeier SA, Kneusel R, Hubbuch J. Downstream processing of virus-like particles: Single-stage and multi-stage aqueous two-phase extraction. J Chromatogr A. 2015;1383:35-46.

114. Sumida E, Iwasaki Y, Akiyoshi K, Kasugai S. Platelet separation from whole blood in an aqueous two-phase system with water-soluble polymers. J Pharmacol Sci. 2006;101:91-7.

115. Kumar A, Kamihira M, Mattiasson B. Two-phase affinity partitioning of animal cells. Implications of multipoint interactions. In: Methods for affinitybased separations of enzymes and proteins. Berlin: Springer; 2002. p. 163-80.

116. Aguilar O, Rito-Palomares M. Aqueous two-phase systems strategies for the recovery and characterization of biological products from plants. J Sci Food Agric. 2010;90:1385-92.

117. Toner M, Irimia D. Blood-on-a-chip. Annu Rev Biomed Eng. 2005;7:77.

118. Soohoo JR, Walker GM. Microfluidic aqueous two phase system for leukocyte concentration from whole blood. Biomed Microdevices. 2009;11:323-9.

119. Zettl R, Feldwisch J, Boland W, Schell J, Palme K. 5'-Azido-[3, 6-3H2]-1napthylphthalamic acid, a photoactivatable probe for naphthylphthalamic acid receptor proteins from higher plants: identification of a 23-kDa protein from maize coleoptile plasma membranes. Proc Natl Acad Sci U S A. 1992; 89:480-4.

120. Hernández LE, Rojas-Ojeda P, Cooke DT, Carpena-Ruiz R. Purification of pea nodule symbiosomes using an aqueous polymer two-phase system. J Chromatogr B. 1996;680:171-81.

121. Edahiro J, Yamada M, Seike S, Kakigi Y, Miyanaga K, Nakamura M, Kanamori T, Seki M. Separation of cultured strawberry cells producing anthocyanins in aqueous two-phase system. J Biosci Bioeng. 2005;100:449-54.

122. Shin H, Han C, Labuz JM, Kim J, Kim J, Cho S, Gho YS, Takayama S, Park J. High-yield isolation of extracellular vesicles using aqueous two-phase system. Sci Rep. 2015;5:13103.

123. Moo-Young M. Comprehensive Biotechnology. Boston: Newnes; 2011.

124. Zhang D-Y, Zu Y-G, Fu Y-J, Wang W, Zhang L, Luo M, Mu F-S, Yao X-H, Duan $\mathrm{M}-\mathrm{H}$. Aqueous two-phase extraction and enrichment of two main flavonoids from pigeon pea roots and the antioxidant activity. Sep Purif Technol. 2013;102:26-33

125. Chethana S, Nayak CA, Raghavarao K. Aqueous two phase extraction for purification and concentration of betalains. J Food Eng. 2007;81:679-87.

126. Wu X, Liang L, Zou Y, Zhao T, Zhao J, Li F, Yang L. Aqueous two-phase extraction, identification and antioxidant activity of anthocyanins from mulberry (Morus atropurpurea Roxb.). Food Chem. 2011;129:443-53.

127. Montalvo-Hernández B, Rito-Palomares M, Benavides J. Recovery of crocins from saffron stigmas (Crocus sativus) in aqueous two-phase systems. J Chromatogr A. 2012;1236:7-15.

128. Chandrasekhar J, Madhusudhan M, Raghavarao K. Extraction of anthocyanins from red cabbage and purification using adsorption. Food Bioprod Process. 2012;90:615-23.

129. Li C-X, Han J, Wang Y, Yan Y-S, Xu X-H, Pan J-M. Extraction and mechanism investigation of trace roxithromycin in real water samples by use of ionic liquid-salt aqueous two-phase system. Anal Chim Acta. 2009;653:178-83.

130. Han J, Wang Y, Yu C-L, Yan Y, Xie X. Extraction and determination of chloramphenicol in feed water, milk, and honey samples using an ionic liquid/sodium citrate aqueous two-phase system coupled with high-performance liquid chromatography. Anal Bioanal Chem. 2011; 399:1295-304. 
131. Cha K-M, Lee E-S, Kim I-W, Cho H-K, Ryu J-H, Kim S-K. Canola oil is an excellent vehicle for eliminating pesticide residues in aqueous ginseng extract. J Ginseng Res. 2015. doi: 10.1016/j.jgr.2015.09.007.

132. Yang X, Yu R, Zhang S, Cao B, Liu Z, Lei L, Li N, Wang Z, Zhang L, Zhang H, Chen $Y$. Aqueous two-phase extraction for determination of triazine herbicides in milk by high-performance liquid chromatography. J Chromatogr B. 2014;972:111-6

133. De Lemos LR, Santos IJB, Rodrigues GD, da Silva LHM, da Silva MCH. Copper recovery from ore by liquid-liquid extraction using aqueous two-phase system. J Hazard Mater. 2012;237-238:209-14.

134. Rodrigues GD, da Silva MCH, da Silva LHM, Paggioli FJ, Minim LA, dos Reis Coimbra JS. Liquid-liquid extraction of metal ions without use of organic solvent. Sep Purif Technol. 2008;62:687-93.

135. De Lemos LR, Campos RA, Rodrigues GD, da Silva LHM, da Silva MCH. Green separation of copper and zinc using triblock copolymer aqueous two-phase systems. Sep Purif Technol. 2013;115:107-13.

136. Rogers $\mathrm{RD}$, Bond $\mathrm{AH}$, Bauer CB. Metal ion separations in polyethylene glycol-based aqueous biphasic systems. Sep Sci Technol. 1993;28:1091-126.

137. Rogers RD, Bond AH, Bauer CB, Zhang J, Griffin ST. Metal ion separations in polyethylene glycol-based aqueous biphasic systems: correlation of partitioning behavior with available thermodynamic hydration data. J Chromatogr B. 1996;680:221-9.

138. Rogers RD, Zhang J. Effects of increasing polymer hydrophobicity on distribution ratios of $\mathrm{TcO} 4$ - in polyethylene/poly (propylene glycol)-based aqueous biphasic systems. J Chromatogr B. 1996;680:231-6.

139. Rogers RD, Griffin ST. Partitioning of mercury in aqueous biphasic systems and on ABEC resins. J Chromatogr B. 1998;711:277-83.

140. Ma J, Guo C, Tang Y, Wang J, Zheng L, Liang X, Chen S, Liu H. Salt-induced micellization of a triblock copolymer in aqueous solution: a $1 \mathrm{H}$ nuclear magnetic resonance spectroscopy study. Langmuir. 2007;23:3075-83.

141. Da Rocha PP, Mesquita MC, da Silva LHM, da Silva MCH. Application of aqueous two-phase systems for the development of a new method of cobalt (II), iron (III) and nickel (II) extraction: a green chemistry approach. J Hazard Mater. 2011;193:311-8.

142. Lacerda VG, Mageste AB, Santos IJB, da Silva LHM, da Silva MCH. Separation of $\mathrm{Cd}$ and $\mathrm{Ni}$ from Ni-Cd batteries by an environmentally safe methodology employing aqueous two-phase systems. J Power Sources. 2009;193:908-13.

143. Zheng $Y$, Tong $Y$, Wang S, Zhang H, Yang Y. Mechanism of gold (III) extraction using a novel ionic liquid-based aqueous two phase system without additional extractants. Sep Purif Technol. 2015;154:123-7.

144. Akama Y, Ito M, Tanaka S. Selective separation of cadmium from cobalt, copper, iron (III) and zinc by water-based two-phase system of tetrabutylammonium bromide. Talanta. 2000;53:645-50.

145. Akama Y, Sali A. Extraction mechanism of $\mathrm{Cr}(\mathrm{VI})$ on the aqueous two-phase system of tetrabutylammonium bromide and $(\mathrm{NH} 4)_{2} \mathrm{SO}_{4}$ mixture. Talanta. 2002:57:681-6

146. Sinha J, Dey P, Panda T. Aqueous two-phase: the system of choice for extractive fermentation. Appl Microbiol Biot. 2000;54:476-86.

147. Banik R, Santhiagu A, Kanari B, Sabarinath C, Upadhyay S. Technological aspects of extractive fermentation using aqueous two-phase systems. World J Microb Biot. 2003;19:337-48.

148. Chavez-Santoscoy A, Benavides J, Vermaas W, Rito-Palomares M. Application of aqueous two-phase systems for the potential extractive fermentation of cyanobacterial products. Chem Eng Technol. 2010;33:177-82.

149. Ferreira AM, Coutinho JA, Fernandes AM, Freire MG. Complete removal of textile dyes from aqueous media using ionic-liquid-based aqueous twophase systems. Sep Purif Technol. 2014;128:58-66.

150. Ivetic DZ, Sciban MB, Vasic VM, Kukic DV, Prodanovic JM, Antov MG. Evaluation of possibility of textile dye removal from wastewater by aqueous two-phase extraction. Desalin Water Treat. 2013;51:1603-8.

151. Robinson T, McMullan G, Marchant R, Nigam P. Remediation of dyes in textile effluent: a critical review on current treatment technologies with a proposed alternative. Bioresource Technol. 2001;77:247-55.

152. Mageste $A B$, de Lemos LR, Ferreira GMD, da Silva MCH, da Silva LHM, Bonomo RCF, Minim LA. Aqueous two-phase systems: an efficient, environmentally safe and economically viable method for purification of natural dye carmine. J Chromatogr A. 2009;1216:7623-9.

153. Huddleston JG, Ingenito CC, Rogers RD. Partitioning behavior of porphyrin dyes in aqueous biphasic systems. Sep Sci Technol. 1999;34:1091-101.

154. Ström GB, Mälarstig B, Blomquist G. Purification of water-based cutting fluids. Method Enzymol. 1994;228:672-8.
155. Huddleston JG, Willauer HD, Boaz KR, Rogers RD. Separation and recovery of food coloring dyes using aqueous biphasic extraction chromatographic resins. J Chromatogr B. 1998;711:237-44.

156. Raghavarao K, Ranganathan T, Srinivas N, Barhate R. Aqueous two phase extraction-an environmentally benign technique. Clean Technol Envir. 2003;5:136-41.

157. Willauer HD, Huddleston JG, Griffin ST, Rogers RD. Partitioning of aromatic molecules in aqueous biphasic systems. Sep Sci Technol. 1999:34:1069-90.

158. Bi P-Y, Dong H-R, Dong J. The recent progress of solvent sublation. J Chromatogr A. 2010;1217:2716-25.

159. Schwienheer C, Prinz A, Zeiner T, Merz J. Separation of active laccases from Pleurotus sapidus culture supernatant using aqueous two-phase systems in centrifugal partition chromatography. J Chromatogr B. 2015; 1002:1-7.

160. Benavides J, Aguilar O, Lapizco-Encinas BH, Rito-Palomares M. Extraction and purification of bioproducts and nanoparticles using aqueous two-phase systems strategies. Chem Eng Technol. 2008;31:838-45.

161. Chen J-P, Lee M-S. Enhanced production of Serratia marcescens chitinase in PEG/dextran aqueous two-phase systems. Enzyme Microb Technol. 1995;17: 1021-7.

162. Helfrich MR, El-Kouedi M, Etherton MR, Keating CD. Partitioning and assembly of metal particles and their bioconjugates in aqueous two-phase systems. Langmuir. 2005;21:8478-86.

163. Benavides J, Rito-Palomares M. Simplified two-stage method to Bphycoerythrin recovery from Porphyridium cruentum. J Chromatogr B. 2006; 844:39-44.

164. Schmidt A, Ventom A, Asenjo J. Partitioning and purification of a-amylase in aqueous two-phase systems. Enzyme Microb Technol. 1994;16:131-42.

165. Ooi CW, Tey BT, Hii SL, Kamal SMM, Lan JCW, Ariff A, Ling TC. Purification of lipase derived from Burkholderia pseudomallei with alcohol/salt-based aqueous two-phase systems. Process Biochem. 2009;44:1083-7.

166. Streitner N, Voß C, Flaschel E. Reverse micellar extraction systems for the purification of pharmaceutical grade plasmid DNA. J Biotechnol. 2007;131: $188-96$

167. Li S, He C, Liu H, Li K, Liu F. Ionic liquid-based aqueous two-phase system, a sample pretreatment procedure prior to high-performance liquid chromatography of opium alkaloids. J Chromatogr B. 2005;826:58-62.

168. Shu Y, Gao M, Wang X, Song R, Lu J, Chen X. Separation of curcuminoids using ionic liquid based aqueous two-phase system coupled with in situ dispersive liquid-liquid microextraction. Talanta. 2016;149:6-12.

169. Xie $X$, Wang $Y$, Han J, Yan $Y$. Extraction mechanism of sulfamethoxazole in water samples using aqueous two-phase systems of poly (propylene glycol) and salt. Anal Chim Acta. 2011;687:61-6.

170. Han J, Wang Y, Yu C, Li C, Yan Y, Liu Y, Wang L. Separation, concentration and determination of chloramphenicol in environment and food using an ionic liquid/salt aqueous two-phase flotation system coupled with high-performance liquid chromatography. Anal Chim Acta. 2011;685:138-45.

171. Chen B, Han J, Wang Y, Sheng C, Liu Y, Zhang G, Yan Y. Separation, enrichment and determination of ciprofloxacin using thermoseparating polymer aqueous two-phase system combined with high performance liquid chromatography in milk, egg, and shrimp samples. Food Chem. 2014; 148:105-11.

172. Shao M, Zhang X, Li N, Shi J, Zhang H, Wang Z, Zhang H, Yu A, Yu Y. Ionic liquid-based aqueous two-phase system extraction of sulfonamides in milk. J Chromatogr B. 2014;961:5-12.

173. Yang X, Zhang S, Yu W, Liu Z, Lei L, Li N, Zhang H, Yu Y. Ionic liquid-anionic surfactant based aqueous two-phase extraction for determination of antibiotics in honey by high-performance liquid chromatography. Talanta. 2014;124:1-6.

174. Lu Y, Yao H, Li C, Han J, Tan Z, Yan Y. Separation, concentration and determination of trace chloramphenicol in shrimp from different waters by using polyoxyethylene lauryl ether-salt aqueous two-phase system coupled with high-performance liquid chromatography. Food Chem. 2016;192:163-70.

175. Show PL, Tan CP, Anuar MS, Ariff A, Yusof YA, Chen SK, Ling TC. Extractive fermentation for improved production and recovery of lipase derived from Burkholderia cepacia using a thermoseparating polymer in aqueous twophase systems. Bioresource Technol. 2012;116:226-33.

176. Viana Marques D, Pessoa-Júnior A, Lima-Filho J, Converti A, Perego P, Porto A. Extractive fermentation of clavulanic acid by Streptomyces DAUFPE 3060 using aqueous two-phase system. Biotechnol Progr. 2011;27:95-103. 
177. Ooi CW, Hii SL, Kamal SMM, Ariff A, Ling TC. Extractive fermentation using aqueous two-phase systems for integrated production and purification of extracellular lipase derived from Burkholderia pseudomallei. Process Biochem. 2011:46:68-73.

178. Pandey S, Banik R. Extractive fermentation for enhanced production of alkaline phosphatase from Bacillus licheniformis MTCC 1483 using aqueous two-phase systems. Bioresource Technol. 2011;102:4226-31.

Submit your next manuscript to BioMed Central and we will help you at every step:

- We accept pre-submission inquiries

- Our selector tool helps you to find the most relevant journal

- We provide round the clock customer support

- Convenient online submission

- Thorough peer review

- Inclusion in PubMed and all major indexing services

- Maximum visibility for your research

Submit your manuscript at www.biomedcentral.com/submit 